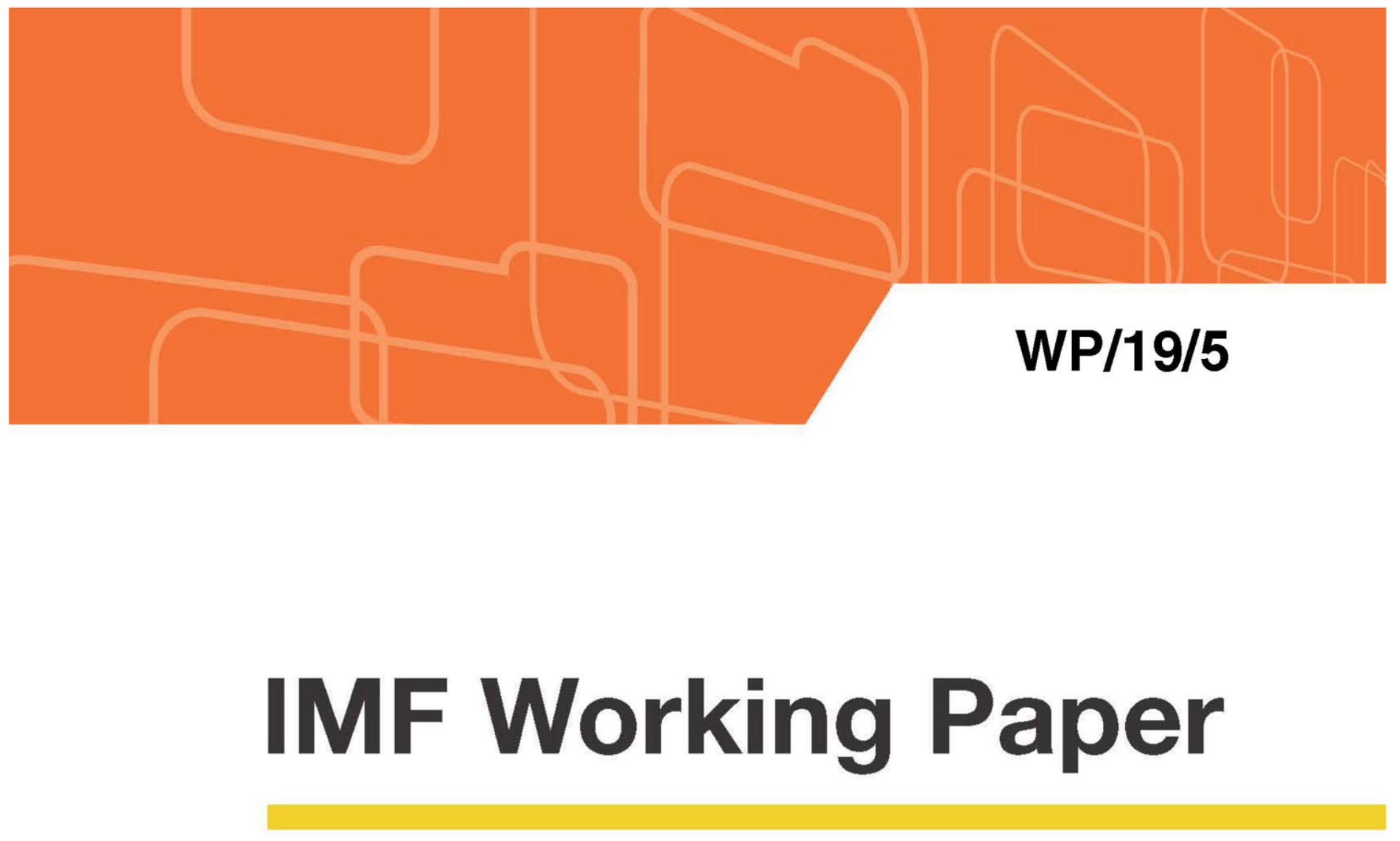

\title{
Bank Profitability and Financial Stability
}

by TengTeng Xu, Kun Hu, and Udaibir S. Das

IMF Working Papers describe research in progress by the author(s) and are published to elicit comments and to encourage debate. The views expressed in IMF Working Papers are those of the author(s) and do not necessarily represent the views of the IMF, its

Executive Board, or IMF management. 


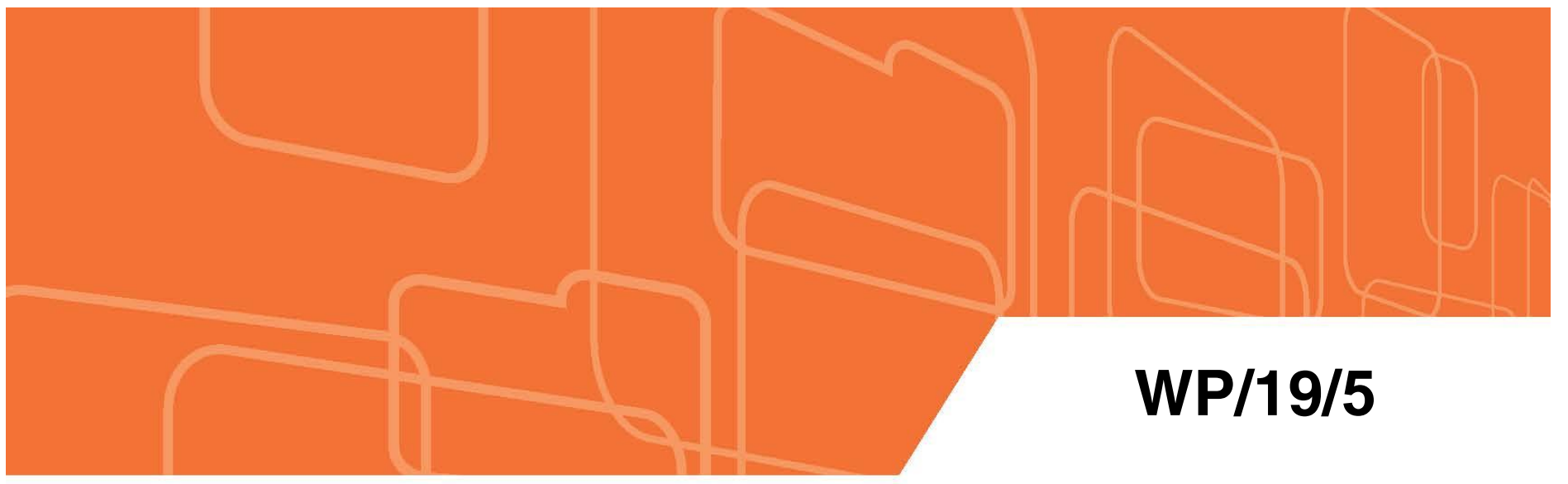

\section{IMF Working Paper}

\section{Bank Profitability and Financial Stability}

by TengTeng Xu, Kun Hu, and Udaibir S. Das

IMF Working Papers describe research in progress by the author(s) and are published to elicit comments and to encourage debate. The views expressed in IMF Working Papers are those of the author(s) and do not necessarily represent the views of the IMF, its Executive Board, or IMF management.

I N T E R N A T I O N A L M O N E T A R Y F U N D 


\title{
IMF Working Paper
}

Monetary and Capital Markets Department

Bank Profitability and Financial Stability

Prepared by TengTeng Xu, Kun Hu, and Udaibir S. Das ${ }^{1}$

Authorized for distribution by Martin Cihak

January 2019

\section{IMF Working Papers describe research in progress by the author(s) and are published to elicit comments and to encourage debate. The views expressed in IMF Working Papers are those of the author(s) and do not necessarily represent the views of the IMF, its Executive Board, or IMF management.}

\begin{abstract}
We analyze how bank profitability impacts financial stability from both theoretical and empirical perspectives. We first develop a theoretical model of the relationship between bank profitability and financial stability by exploring the role of non-interest income and retailoriented business models. We then conduct panel regression analysis to examine the empirical determinants of bank risks and profitability, and how the level and the source of bank profitability affect risks for 431 publicly traded banks (U.S., advanced Europe, and GSIBs) from 2004 to 2017 . Results reveal that profitability is negatively associated with both a bank's contribution to systemic risk and its idiosyncratic risk, and an over-reliance on noninterest income, wholesale funding and leverage is associated with higher risks. Low competition is associated with low idiosyncratic risk but a high contribution to systemic risk. Lastly, the problem loans ratio and the cost-to-income ratio are found to be key factors that influence bank profitability. The paper's findings suggest that policy makers should strive to better understand the source of bank profitability, especially where there is an over-reliance on market-based non-interest income, leverage, and wholesale funding.
\end{abstract}

JEL Classification Numbers: G10, G20 and C23.

Keywords: Finanical stability, bank profitability, systemic risk, non-interest income, business model, panel regression.

Author E-Mail Addresses: txu@imf.org, rickhukun@ucla.edu, udas@imf.org.

\footnotetext{
${ }^{1}$ We are grateful to John Caparusso, Martin Cihak, Ehsan Ebrahimy, Javier Hamann, Fei Han, Mindaugas Leika, Graeme Littler, Hiroko Oura, Yizhi Xu, and the participants of the IMF's MCM Quantum Seminar for useful feedback. All remaining errors are our own.
} 


\section{Contents}

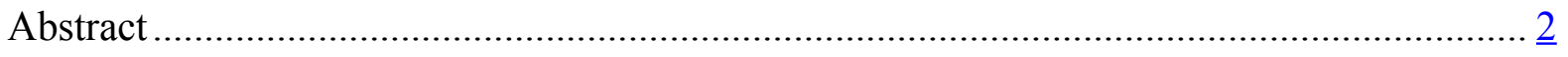

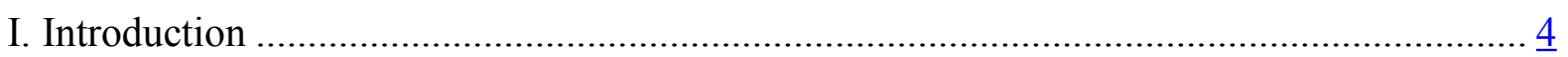

II. Bank Profitability and Risks: A Stylized Theoretical Model......................................... 7

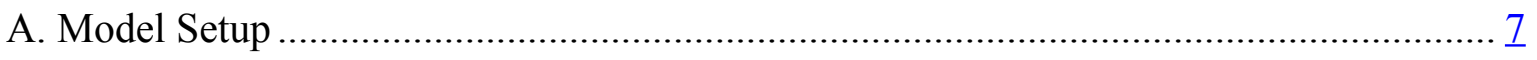

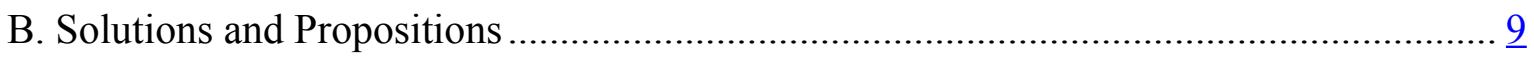

C. Extension with Bank Charter Value ....................................................................... 14

III. Stylized Facts and Empirical Methodology …..................................................... 18

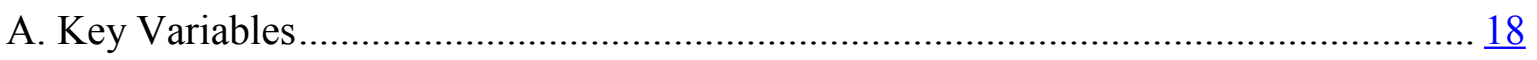

B. Stylized Facts ................................................................................................. 21

C. Hypotheses and Empirical Methodology ................................................................ 24

IV. Empirical Findings on the Determinants of Risks and Profitability ............................ 25

A. Profitability, Business Models, and Financial Stability ......................................... 25

B. Determinants of Bank Profitability ................................................................... $\underline{30}$

V. Policy Implications and Conclusions ................................................................... $\underline{32}$

Appendix I: A Selected Literature Review ................................................................. 34

Appendix II: Proofs of Propositions and Lemmas........................................................ $\underline{36}$

Appendix III: Data Sources and Definitions................................................................ 42

Appendix IV: Robustness Checks ...................................................................... 45

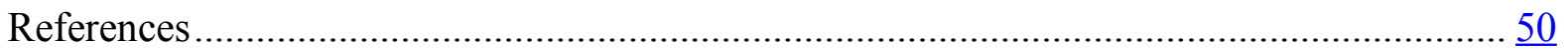




\section{INTRODUCTION}

The Global Financial Crisis (GFC) of 2007-2009 and the ensuing period of low interest rates have renewed interest among policy makers on the importance of bank profitability for financial stability. Despite the subsequent recovery, the return on equity of many banks remains below the cost of equity. With valuations below the balance sheet value of banks, ${ }^{2}$ the market's assessment of banks' ability to overcome profitability challenges is not optimistic.

The existing literature on bank profitability and its impact on financial stability reports mixed evidence. First, on profitability and risks, some researchers found that higher profitability leads to higher "charter value" (i.e., long-term expected profitability) and therefore less risktaking by banks (Keeley 1990; Berger, Klapper, and Turk-Ariss 2009). Others suggest that high profitability could loosen leverage constraints and lead to more risk-taking (Natalya, Ratnovski, and Vlahu 2015). Furthermore, high profits in good times could be an indicator of systemic tail risk in bad times (Meiselman, Nagel, and Purnanandam 2018). Second, there is mixed evidence on the impact of non-interest income (NII) on risks (Baele, De Jonghe, and Vander Vennet 2007; Elsas, Hackethal, and Holzhauser 2010). More recently, some researchers found that the impact on financial stability depends on the type of non-interest income (Kohler 2014; DeYoung and Torna 2013).

Motivated by such mixed evidence, this paper addresses two mains issues. First, we investigate the theoretical and empirical relationships between bank profitability and financial stability, taking into account bank business models (e.g., retail vs. wholesale orientation) and different types of NII activities. In this regard, we analyze not only the link between the level of bank profitability and financial stability, but also the deeper question of how the source of bank profitability affects financial stability. Several measures of bank business models and characteristics shed light on the source of bank profitability. For example: the NII share and the loan-to-asset (LTA) ratio provide insights on banks' reliance on NII and non-traditional business or activities; the deposit-to-liability ratio captures the extent to which banks rely on wholesale funding to cut costs on the liability side of the balance sheet ${ }^{3}$; the leverage ratio in part reflects banks' risk-taking behavior and the risks undertaken by banks to generate income; and competition measures such as the Lerner index of a firm's market power captures the extent to which banks rely on mark-up and market power to make profits. Second, we examine the importance of the different determinants of banking risks and profitability, capturing bank business models and characteristics, structural and cyclical conditions, and policies.

\footnotetext{
2 The low profitability of banks has been highlighted recently in the IMF's Global Financial Stability Reports (October 2016, 2017) and IMF led Financial Sector Assessment Programs (Euro Area 2018, Spain 2017, Japan 2017, Germany 2016, and Ireland 2016).

${ }^{3}$ While wholesale funding provided cost savings prior to the crisis, there is some evidence that it became more expensive than retail funding after the crisis in some countries.
}

(continued...) 
This paper begins by setting out a stylized theoretical model that underpins the analytical relationship between bank profitability and financial stability by explicitly capturing the role of NII and retail-oriented business models. In this model, banks choose the amount of retailoriented and market-oriented NII activities ${ }^{4}$ to maximize expected equity values, given the risk profile of these activities. The key mechanism in our theoretical model is the complementarity between retail-oriented NII activities and bank lending. When the LTA ratio is high, banks are more inclined to engage in retail-oriented NII activities given the existing retail client base. On the other hand, when the LTA ratio is low, banks may choose to engage in market-oriented NII activities which tend to be riskier and providing limited diversification benefit from a financial stability prospective.

The theoretical model predicts that idiosyncratic risk, defined as the value-at-risk (VaR) of equity and the expected default frequency (EDF) proxy, decreases as both short-term book profitability (i.e., return on average assets, or ROAA) and long-term expected profitability (i.e., charter value) rise. Profits reduce risks by providing equity buffers and encouraging prudence, thereby reducing risk-taking. In addition, when the LTA ratio is below a certain threshold, idiosyncratic risk increases as the NII share ${ }^{5}$ rises. We derive testable hypotheses on the relationship among bank profitability, business models, and financial stability.

In the empirical analysis, we apply dynamic panel regression approaches to examine the determinants of financial stability and profitability, and test the hypotheses derived from the theoretical model. Financial stability is captured by both idiosyncratic and systemic risk measures. Idiosyncratic risk is measured by market-based risk measures, including the historical VaR of equity prices and Moody's EDF, while the contribution to systemic risk is measured by the delta CoVaR (Adrian and Brunnermeier 2016). Bank profitability is measured by ROAA, ROAE (return on average equity), risk-adjusted returns, and the priceto-book ratio (a proxy for charter value). To analyze the determinants of risks and bank profitability, we not only control for business model measures, but also more generally, bank characteristics, structural and cyclical conditions, as well as monetary and fiscal policy variables. In our empirical analysis, we examine the "average" relationship between bank profitability, business models, and financial stability from 2004 to 2017, capturing both crisis and normal times. In this sense, our analysis is more general compared with papers that focus on crisis episodes alone. We focus our attention on 431 publicly traded banks as we capture market-based measures of bank profitability and financial stability.

Empirical results reveal several important interactions among bank profitability, business models, and financial stability, and confirm the hypotheses from the theoretical model. First, profitability (ROAA) and the price-to-book ratio are negatively associated with both the contribution to systemic risk (delta CoVaR) and idiosyncratic risks measured by the VaR (95 percent $\left.{ }^{6}\right)$ and the EDF of banks. Second, a high NII share tends to be associated with higher

\footnotetext{
${ }^{4}$ Market-oriented business lines include underwriting, trade execution commissions, and investment-banking service. Retail-oriented business includes payment services fees, insurance commissions, and fiduciary income. The risk and return profile depend on the specific NII activity. For a summary of stylized facts, see Stiroh (2004).

5 The NII share is defined as the ratio of NII to operating income.

${ }^{6}$ We define VaR as the $95 \%$ quantile of "loss," which is the inverse of rate of return.
} 
idiosyncratic and contribution to systemic risks when the LTA is low (i.e., when a bank's business model is less retail-oriented), as predicted by our theoretical model. Third, low competition is associated with lower idiosyncratic risk but higher contribution to systemic risk. In addition, our results confirm that high leverage and an over-reliance on wholesale funding are associated with higher idiosyncratic and contribution to systemic risks. Finally, on the determinants of bank profitability (ROAA, ROAE, and risk-adjusted returns) and the price-to-book ratio, high problem loans ratios, high funding costs, and low-cost efficiency (cost-to-income ratio) are associated with low bank profitability.

This paper contributes to the existing literature on bank profitability and financial stability from both theoretical and empirical perspectives. ${ }^{7}$ Theoretically, this paper provides one of the first models to pin down the analytical relationship between risks and bank profitability, accounting for the interaction between NII and retail-oriented business models. Most papers focus on a narrow set of NII activities, especially market-oriented ones such as securitization and trading (e.g., Shleifer and Vishny 2010; Boot and Ratnovski 2016), yet fee-based traditional retail-oriented business is another crucial component of NII. In our model, we consider both retail-based and market-based NII and the distinction is general in nature: only the former is complementary with respect to bank lending. We then derive explicitly the impact of bank profitability, the NII share, and the LTA ratio on idiosyncratic risks measured by $\mathrm{VaR}$ and $\mathrm{EDF}$.

The empirical contribution of our paper is three-fold. First, the paper is one of the first comprehensive empirical analysis on the determinants of bank idiosyncratic risks and their contribution to systemic risks, accounting for bank profitability, business models, structural and cyclical conditions, and policy responses during recent crises. Second, we contribute to the empirical literature on NII and their financial stability implications by explicitly controlling for retail vs. wholesale business models in a cross-country setting without reliance on confidential supervisory data. Earlier papers either used detailed supervisory data or categorize NII according to local accounting standards in country-specific studies (e.g., Kohler 2014; DeYoung and Torna 2013). In this paper, using an interaction term between share of NII and the LTA ratio, we are able to control for the type of NII activities and bank business models in a cross-country setting, even when accounting standards differ across countries. ${ }^{8}$ Third, we examine the relationship between the forward-looking measure of risks (EDF) and bank profitability empirically. Earlier literature has largely focused on backwardlooking measures (DeYoung and Torna 2013).

Finally, our paper contributes to policy discussions on the role of bank profitability for financial stability. The results demonstrate that the source and the sustainability of bank profitability has important financial stability implications, as an over-reliance on marketbased NII activities, leverage, and wholesale funding is associated with higher idiosyncratic risk and contribution to systemic risk. Furthermore, the impact of bank consolidation on

\footnotetext{
${ }^{7}$ A literature survey on the determinants of risks and bank profitability can be found in Appendix I.

${ }^{8}$ Furthermore, publicly available data sources such as the S\&P Global Market Intelligence's SNL database and Fitch Connect do not provide further breakdown on the type of NII and loans in a consistent manner across countries, in part, due to different accounting standards and reporting requirements among countries.
} 
competition should be addressed in policy discussions, as low competition is associated with a high contribution to systemic risk.

The rest of the paper is structured as follows. We first present a stylized theoretical model on the relationship between profitability and financial stability in Section II. Section III presents the data, stylized facts, and the empirical methodology. We then discuss the empirical findings on the determinants of risk and bank profitability in Section IV. Finally, we offer some concluding remarks and discuss policy implications in Section V.

\section{Bank Profitability and Risks: A Stylized Theoretical Model}

To anchor analytical relationships between bank profitability and financial stability, we outline below a stylized model accounting for bank business models. The focus of the model is to capture both retailed-based and market-based NII activities, and the non-linear impact of NII on banking risks. To keep it tractable and focused, we abstract from modelling a dynamic programming problem, as it is not essential for capturing the stylized relationships among bank profitability, business models, and financial stability.

\section{A. Model Setup}

\section{Bank Balance Sheet}

In the stylized theoretical model, we consider a static setting of a representative risk-neutral bank with the following balance sheet structure:

\begin{tabular}{cc} 
Assets & Liabilities \\
\hline \hline$L$ & $D$ \\
$N_{r}$ & $E$ \\
$N_{m}$ &
\end{tabular}

The balance sheet constraint is given by

$$
L+N_{r}+N_{m}=D+E \equiv A,
$$

where $N_{m}$ stands for the assets related to market-based NII activities, such as underwriting, trade commissions, and investment-banking services, and $N_{r}$ captures retail-based NII activities, such as payment services fees, insurance commissions, lending service fees, and fiduciary income. $N_{r}$ and $N_{m}$ are the assets devoted to NII activities at the beginning of the period. ${ }^{9} L$ represents loans, $D$ deposits, $E$ equity, and $A$ bank assets. For simplicity and tractability, we assume $D, L$ and $E$ to be exogenous, and that the capital constraint is binding, $E=e A$, where $e$ is the reciprocal of the leverage ratio. The assumption that $L$ is exogenous is not unreasonable in our stylized model, as $L$ can be regarded as a proxy for the retail

\footnotetext{
${ }^{9}$ For example, if retail-based NII includes payment service fees, then $N_{r}$ represents the payment network or system's assets (e.g., ATMs, software, machinery).
} 
customer base of a bank and typically cannot change quickly. Similar reasoning is applied to equity $E$ by assuming some equity issuance costs or frictions.

\section{Bank Profit Function and Shocks}

The bank's profit function is given as

$$
\widetilde{\Pi}=(1-x) \tilde{r}_{L} L+\tilde{r}_{m} N_{m}+\tilde{r}_{r} N_{r}^{\alpha} L^{1-\alpha}-c_{m} N_{m}-c_{r} N_{r}-c_{f} A-r_{D} D,
$$

where tilde " $\sim$ " denotes random variables, and returns are normally distributed as $\tilde{r}_{i} \sim N\left(r_{i}, \sigma_{i}^{2}\right)$ with $i=L, m, r$. For simplicity, we assume $\tilde{r}_{i}$ are mutually independent. ${ }^{10}$ $c_{m}, c_{r}$, and $c_{f}$ are cost parameters where $c_{m}<r_{m} . r_{D}$ is the deposit rate and $x$ denotes the problem loan ratio. The deposit rate $r_{D}$ can be viewed as funding cost in our stylized model.

A key structure in the model is the Cobb-Douglas production function $N_{r}^{\alpha} L^{1-\alpha}$ of retailbased NII activities. ${ }^{11}$ It ensures homogeneity of degree one with respect to inputs $L$ and $N_{r}$, as well as the complementarity between retail-based lending business $L$, and retail-based NII activities $N_{r}$. The complementarity is motivated by the fact that most retail-based NII activities share the same customer base (and some employee skills) as the lending business.

\section{Bank Objective Function}

The bank's objective function is given by

$$
\max _{N_{m}, N_{r}} \mathbf{E}(\widetilde{\Pi})+E
$$

subject to the balance sheet constraint $L+N_{r}+N_{m}=D+E$. Note that the bank's survival probability is given by $q=\operatorname{Prob}(\widetilde{\Pi}+E \geq 0)$. Following Matutes and Vives (1996), we abstract from the assumption of limited liability.

We normalize the bank's objective function by bank asset $A$ and take expectations. The normalized objective function is then given by

$$
\max _{n_{m}, n_{r}} \mu_{\pi}+e
$$

\footnotetext{
10 This assumption is not important and will not alter the main results. For details, please refer to the discussions after proposition 2 .

11 The specific functional forms for the returns on retail-oriented NII $\left(N_{r}\right)$ and market-oriented NII $\left(N_{m}\right)$ are not critical for the theoretical results. Instead of the linear specification of the return on $N_{m}$, one can also assume a Cobb-Douglas production function, $N_{m}^{\beta} L^{1-\beta}$, where $\beta>\alpha$ for the market-based NII activities. The underlying reason for $\beta>\alpha$ is that retail-oriented NII is expected to have more complementarity with bank lending than with market-oriented NII activities. In other words, there could be complementarities between market-based NII activities and bank lending, but the degree of complementarity between retail-based NII activities and bank lending is expected to be higher than that of market-based ones.
} 
subject to $l+n_{r}+n_{m}=1$, where

$$
\begin{gathered}
\mu_{\pi} \equiv \frac{\mathbf{E}(\widetilde{\Pi})}{A} \equiv \mathbf{E}(\widetilde{\pi})=(1-x) r_{L} l+r_{m} n_{m}+r_{r} n_{r}^{\alpha} l^{1-\alpha}-c_{m} n_{m}-c_{r} n_{r}-c_{f}-r_{D}(1-e), \\
e=\frac{E}{A}, l=\frac{L}{A}, n_{M}=\frac{N_{M}}{A}, n_{r}=\frac{N_{r}}{A}
\end{gathered}
$$

Note that $n_{m}$ and $n_{r}$ capture market-based and retail-based NII intensity (share of NII activities in bank asset, different from income), $l$ is the LTA ratio, and $\mu_{\pi}$ captures the expected return on asset (ROA).

\section{Definition of Risks}

As we are interested in the relationships between bank profitability and financial stability, we focus on two types of risks that are particularly relevant for financial stability considerations. First, we consider the default probability of a bank, measured by its overall credit risk or solvency. Second, we are interested in the tail risks faced by a bank. Based on our stylized theoretical model, we define the EDF proxy (default probability) and the VaR of individual banks as follows:

Expected Default Frequency Proxy (EDF)

$$
E D F \equiv 1-q=\operatorname{Prob}(\widetilde{\pi}+e<0) .
$$

The EDF proxy is defined as one minus the survival probability of the bank. ${ }^{12} \mathrm{~A}$ bank defaults in our model when equity is below zero.

Value-at-Risk (VaR)

$$
\operatorname{Prob}(|\operatorname{Loss}| \geq \operatorname{VaR})=\operatorname{Prob}(-\widetilde{\pi}-e \geq \operatorname{VaR})=0.05 .
$$

The VaR is defined as the 95 percentile of equity loss in this model, where higher $\mathrm{VaR}$ signifies higher tail risks.

\section{B. Solutions and Propositions}

We solve the bank's optimization problem by taking first order conditions with respect to $n_{m}$ and $n_{r}$, subject to its budget constraint. The resulting first order conditions are given as follows:

$$
\begin{aligned}
& {\left[n_{m}\right]: \quad r_{m}=c_{m}+\varphi \text { if } n_{m}>0,} \\
& {\left[n_{r}\right]: \quad \alpha r_{r} n_{r}^{\alpha-1} l^{1-\alpha}=c_{r}+\varphi \text { if } n_{m}>0,}
\end{aligned}
$$

\footnotetext{
${ }^{12}$ This definition of the EDF proxy is applicable to a more general concept of default probability.
} 
where $\varphi$ is the Lagrange multiplier of $l+n_{r}+n_{m}=1$.

We then rewrite the first order conditions with superscript $*$ denoting the optimal value of choice variables:

$$
\begin{aligned}
& \text { If } l \geq \frac{1}{1+k}: \quad n_{r}^{*}=1-l, n_{m}^{*}=0 \text { and } n_{r}^{*} / n_{m}^{*}=\infty, \\
& \text { If } l<\frac{1}{1+k}: \quad n_{r}^{*}=k l, n_{m}^{*}=1-l-k l \text { and } n_{r}^{*} / n_{m}^{*}=\frac{k l}{1-l-k l}, \\
& \text { where } k=\left(\frac{\alpha r_{r}}{c_{r}+r_{m}-c_{m}}\right)^{\frac{1}{1-\alpha}}>0 .
\end{aligned}
$$

If $l<\frac{1}{1+k}$, the first order conditions imply an interior solution where the optimal retail-based NII intensity $n_{r}^{*}$ is a positive function of the LTA ratio $l$, reflecting the complementarity between $n_{r}$ and $l$. If $l \geq \frac{1}{1+k}$, the first order conditions imply a corner solution where the optimal market-based NII intensity $n_{m}^{*}$ is equal to zero (Figure 1, left panel).

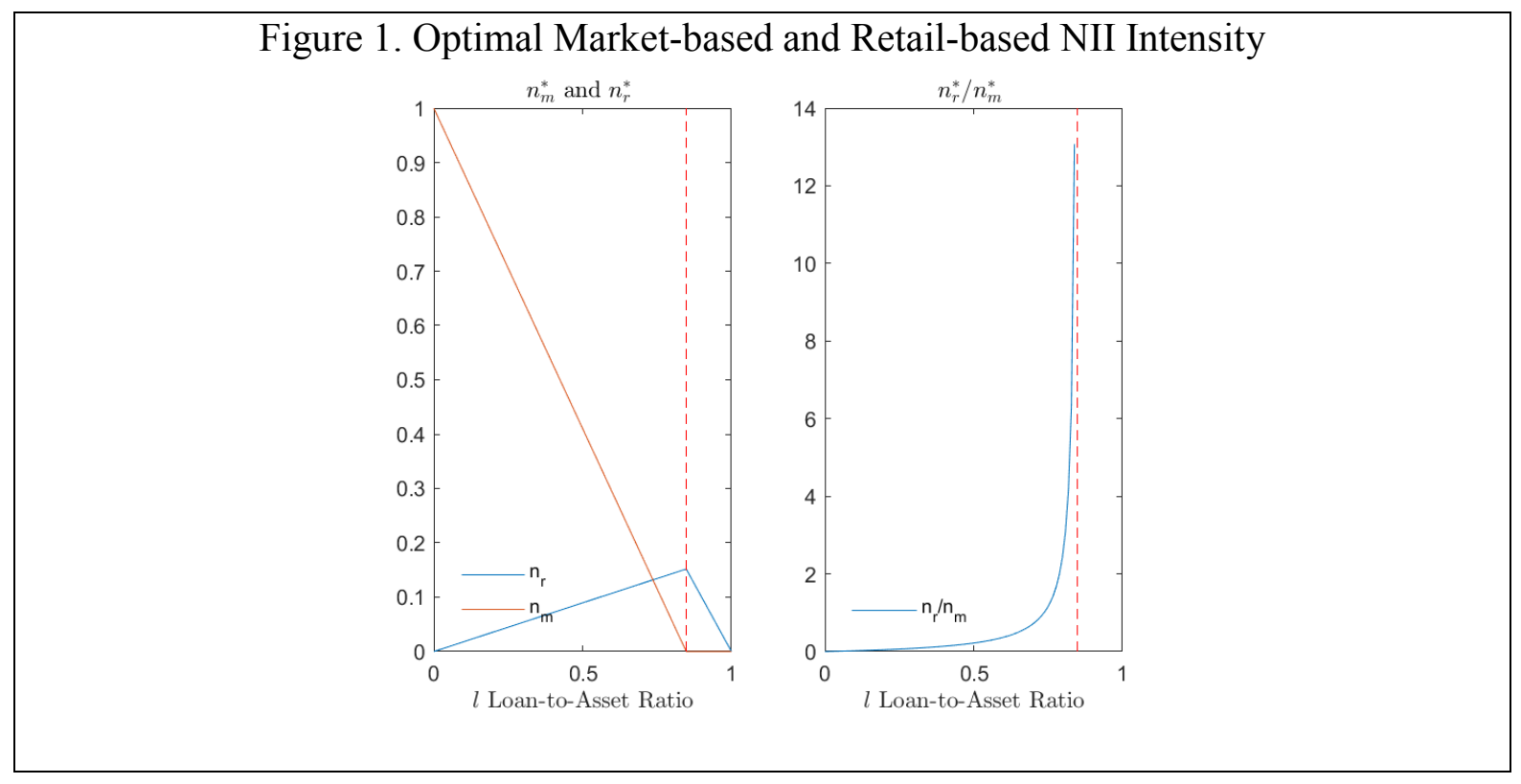

\section{Risks and Profitability}

Based on the model solutions, we can derive Proposition 1 on the relationship between bank risks and profitability.

Proposition 1: Bank idiosyncratic risks measured by EDF and VaR are decreasing in the (expected) $R O A \mu_{\pi}^{*}$ 


$$
\frac{\partial E D F}{\partial \mu_{\pi}^{*}}<0, \quad \frac{\partial V a R}{\partial \mu_{\pi}^{*}}<0
$$

Proof: See Appendix II.

The intuition for the negative relationship between idiosyncratic risks and bank profitability is that per-period profit $\mu_{\pi}^{*}$ (or the book value of profit) provides a buffer against negative shocks to bank capital. Higher $\mu_{\pi}^{*}$ means larger buffers and reduced default risk, which lowers idiosyncratic risks. ${ }^{13}$

\section{Risks, NII, and the LTA Ratio}

Having established the analytical relationship between bank profitability and risks, we next examine the source of bank profitability and the relationship to bank risks. We are particularly interested in the role of NII activities for risks, accounting for bank business models. From the first order conditions of the model, we derive the Lemma 1 below.

Lemma 1: The ratio of retail-based NII intensity to market-based NII intensity is increasing in the LTA ratio:

$$
\frac{\partial\left(n_{r}^{*} / n_{m}^{*}\right)}{\partial l} \geq 0
$$

Proof: From the solution to first order conditions, we have

$$
\begin{array}{lc}
\text { If } l \geq \frac{1}{1+k}: & \frac{\partial\left(n_{r}^{*} / n_{m}^{*}\right)}{\partial l}=0, \\
\text { If } l<\frac{1}{1+k}: & \frac{\partial\left(n_{r}^{*} / n_{m}^{*}\right)}{\partial l}=\frac{k}{(1-l-k l)^{2}}>0 .
\end{array}
$$

Q.E.D.

Lemma 1 states that the composition of NII will change with respect to the LTA ratio. The result is also shown in the right panel in the Figure $1 .{ }^{14}$ Intuitively, this result follows from the complementarity between $n_{r}$ and $l$, because of the term $n_{r}^{\alpha} l^{1-\alpha}$ in expected profitability $\mu_{\pi}$. The LTA ratio $l$ is a proxy of the retail business for a bank. Higher $l$ is associated with more retail clients, which makes developing retail-based NII activities "easier" (the marginal

\footnotetext{
${ }^{13}$ Some papers that internalize borrowers' decisions argue that if lower profitability is a result of lower interest rate margins, then reduced credit rationing in the loan market will improve the average quality of loan applicants, which ultimately translates to lower bank risks (Boyd and De Nicolo 2005; Stiglitz and Weiss 1981). Given that interest rates were very low in our sample period of 2004 to 2017, it is reasonable to abstract from the credit rationing channel. Instead, we focus on the equity buffer channel and the charter value channel of bank profitability in our stylized theoretical model.

${ }^{14}$ In Figure 1, at the red dotted line $l=\frac{1}{1+k}$, the bank's optimization problem yields a corner solution as $n_{m}^{*}=$ 0 .
} 
benefit of $n_{r}$ depicted by $\alpha n_{r}^{\alpha-1} l^{1-\alpha}$ increases in $l$ ). So a high-l bank willingly leans toward more retail-based NII, and $n_{r}^{*} / n_{m}^{*}$ increases.

Denote the (expected) share of the (overall) NII as

$$
s=\frac{N I I}{N I I+I I}=\frac{r_{m} n_{m}^{*}+r_{r} n_{r}^{* \alpha} l^{1-\alpha}}{r_{m} n_{m}^{*}+r_{r} n_{r}^{* \alpha} l^{1-\alpha}+(1-x) r_{L} l} .
$$

Under the interior solution, when $l<\frac{1}{1+k}$, the share of NII $s$ can be rewritten as $s=\frac{r_{m}-c_{m}-(1+k) l\left(r_{m}-c_{m}\right)+\left(r_{r} k^{\alpha}-c_{r} k\right) l}{r_{m}-c_{m}-(1+k) l\left(r_{m}-c_{m}\right)+\left(r_{r} k^{\alpha}-c_{r} k\right) l+(1-x) r_{L} l}$ and it is straight forward to show that $\frac{\partial s}{\partial n}=\frac{\partial s}{\partial\left(n_{r}+n_{m}\right)}=\frac{\partial s}{\partial(1-l)}=-\frac{\partial s}{\partial l}>0$. In other words, the expected NII share is increasing in total NII intensity $n_{r}+n_{m}$. This leads to the following proposition regarding NII activities and bank risks.

Proposition 2: When LTA ratio (l) is below a certain threshold (l), higher NII share (s) will lead to higher VaR and EDF:

$$
\frac{\partial E D F}{\partial s}>0, \quad \frac{\partial V a R}{\partial s}>0, \text { if } l \leq \underline{l}
$$

under a regularity condition ${ }^{15}$ and where $\underline{l}=\frac{(1+k) \sigma_{m}^{2}}{(1-x)^{2} \sigma_{L}^{2}+(1+k)^{2} \sigma_{m}^{2}+k^{2 \alpha} \sigma_{r}^{2}}<\frac{1}{1+k}$.

Proof: See Appendix II.

The effect of the NII share on idiosyncratic risks (VaR and EDF) are illustrated in Figure 2. The dotted blue line denotes $\underline{l}$. When $l \leq \underline{l}$, the partial derivatives are positive, meaning that increasing NII share will result in higher idiosyncratic risks. This is because, as noted in Lemma $1, n_{r}^{*} / n_{m}^{*}$ decreases as $l$ declines.

To understand the underlying mechanism, note that bank assets are a portfolio consisting of three sources of return: loans, market-based NII activities, and retail-based NII activities. In order words, the overall bank idiosyncratic risk is a function of the portfolio weights (and variance-covariance structure). If $l$ is small enough $(l \leq \underline{l}), n_{r}^{*} / n_{m}^{*}$ will also be sufficiently low that banks become over-reliant on market-based NII activities. If the bank's portfolio weighs heavily on one source of return (i.e., $n_{r}^{*} / n_{m}^{*}$ is very small), the overall portfolio risks increase.

Proposition 2 does not rely on further assumptions on the return or risk structure of $\tilde{r}_{L}, \tilde{r}_{m}$, and $\tilde{r}_{r}$, as long as they are not perfectly correlated. This is also related to the

\footnotetext{
15 The regularity condition is that the problem loan ratio $x<1+\frac{\left(r_{m}-c_{m}\right)\left(\frac{1-\alpha}{\alpha} k-1\right)+\frac{1-\alpha}{\alpha} k c_{r}}{r_{L}}$. This parameter
} assumption is reasonable, as the average value of $x$ observed empirically in our sample is less than $5 \%$. 
portfolio interpretation: as long as sources of return are not perfectly correlated, there is gain from diversification. If we allow for correlation among the three different returns $\left(\tilde{r}_{L}, \tilde{r}_{m}\right.$, and $\left.\tilde{r}_{r}\right), \underline{l}$ will adjust accordingly but the conclusions from Proposition 2 remain the same. For example, if $\tilde{r}_{L}$ and $\tilde{r}_{r}$ follow a bivariate normal distribution with correlation coefficient $\rho$, the threshold for the LTA ratio $\underline{l}$ becomes

$\underline{l}=\frac{(1+k) \sigma_{m}^{2}}{(1-x)^{2} \sigma_{L}^{2}+(1+k)^{2} \sigma_{m}^{2}+k^{2 \alpha} \sigma_{r}^{2}+a(1-x) l k^{\alpha} \rho \sigma_{L} \sigma_{r}}$.

It should be noted that $\underline{l}$ is increasing in $\sigma_{m}^{2}$, meaning that the more volatile the market-based NII is (e.g., if $\sigma_{m}^{2} \geq \sigma_{r}^{2}$ ), the higher the threshold of the LTA ratio, or the easier it is for a bank to reach the tipping point of NII share $s$ where higher NII will translate to higher risks.

Our theoretical finding is consistent with that of Natalya, Ratnovski, and Vlahu (2018) and Meiselman, Nagel, and Purnanandam (2018), which suggest that NII activities could lead to higher risks. The former propose that higher profitability in core business relaxes a bank's leverage constraint, enabling more risk-taking in non-core (i.e., NII) business. The latter also argue that NII is the main culprit of highly volatile returns (high profit in "good times" and high loss in "bad times"). Given that NII is a broad catogory, with distint risks for different NII components (Stiroh 2004), our model endogenizes a bank's decision on which NII activities to focus on, which in turn draws different predictions on the effect of NII activities on bank risks.

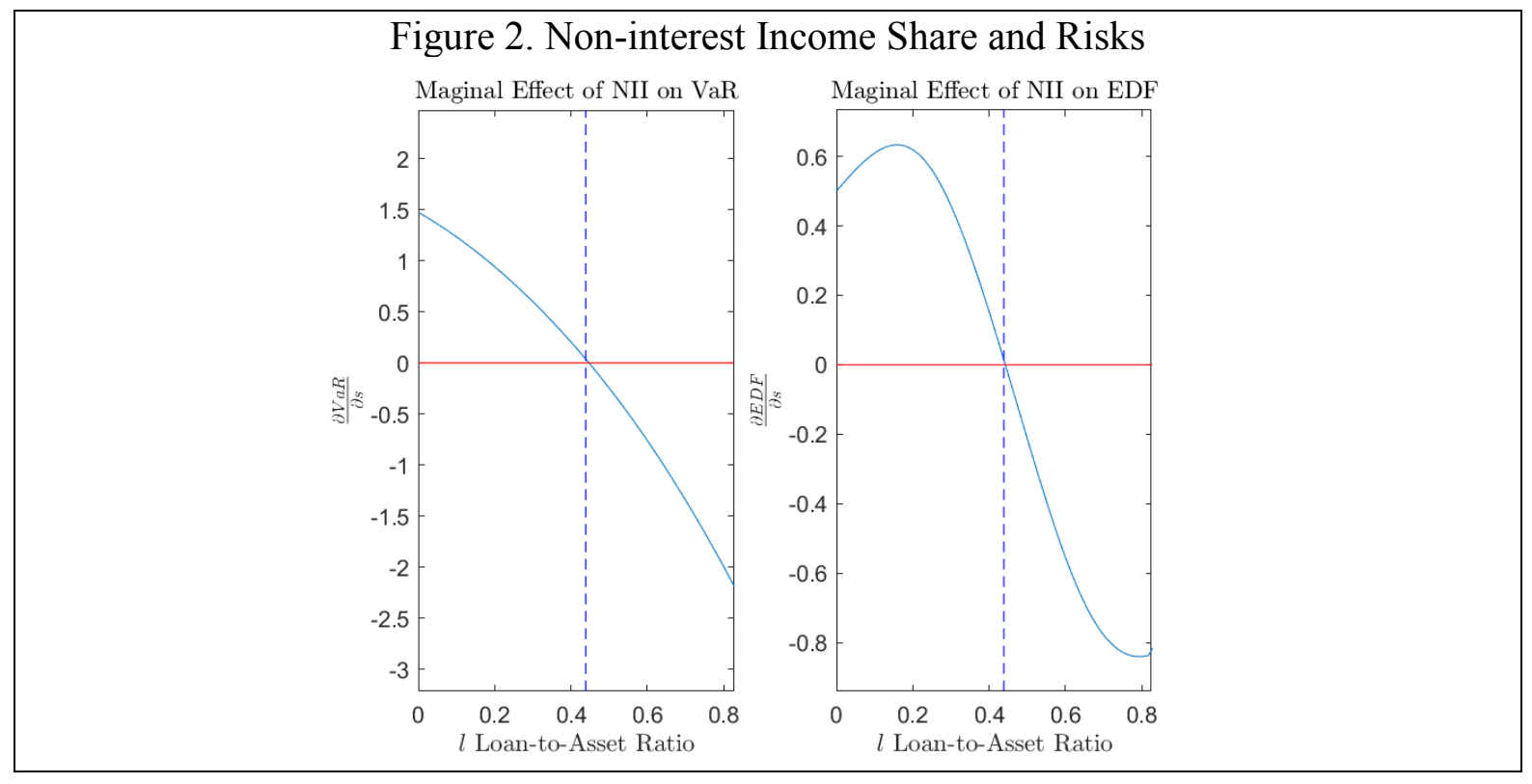

\section{Discussion of Systemic Risks}

Besides idiosyncratic risks, the activities of a financial institution can contribute to systemic risk (i.e., to the overall financial system). Many empirical measures of systemic risks, including the delta CoVaR that we use in the empirical analysis, are functions of a bank's 
systematic risks (or beta), as the two concepts are closely related. If a bank's contribution to systemic risk is high, its correlation with financial market conditions is also expectedly high (see Meiselman, Nagel, and Purnanandam 2018). Among the various types of bank activities, market-focused ones (e.g., securitization and derivative trading) are shown to have higher systemic risks (De Jonghe, Diepstraten, and Schepens 2015; Brunnermeier, Dong, and Palia 2012; Engle et al. 2014). Mapped to our model, a higher value of $n_{m}$ is then expected to contribute to higher systemic risks, consistent with the predictions for idiosyncratic risks in Proposition 2.

\section{Determinants of Profitability}

Having established that the profitability measure $\mu_{\pi}$ (ROA) impacts risks, we examine the determinants of profitability. One option is to pin down the analytical relationship between bank profitability and its determinants directly from its profit function. What follows is the following proposition:

Proposition 3: Expected profits are decreasing in the problem loan ratio $x$, the operating $\operatorname{cost} c_{f}$, and the funding cost $r_{D}$

$$
\frac{\partial \mu_{\pi}^{*}}{\partial x}<0 \quad \frac{\partial \mu_{\pi}^{*}}{\partial c_{f}}<0 \quad \frac{\partial \mu_{\pi}^{*}}{\partial r_{D}}<0 .
$$

Proof: See Appendix II.

Proposition 3 is consistent with the accounting relationship in a bank's balance sheet.

Intuitively, higher problem loan ratios could lead to more provisioning for non-performing loans (NPLs), which would then weigh on bank profitability. In addition, higher costs either from the operating side or the funding side would reduce bank profits. While there is some empirical evidence that high NPL ratios and costs are associated with low profitability (IMF 2017), there is limited prior theoretical work to formalize this relationship. As a result, we include Proposition 3 to provide some theoretical underpinning to motivate the empirical analysis on the determinants of bank profitability in our paper.

\section{Extension with Bank Charter Value}

In addition to the book value of profitability (or per period profit), another common measure of profitability is the price-to-book ratio, which can be interpreted as the charter value of a bank, or a function of all future profits. A high charter value can have a disciplinary effect on bank risk-taking behavior. Motivated by this consideration, we extend our baseline model to include the interaction of bank charter value and idiosyncratic risks. For analytical simplicity, we consider a case where a bank has already made the optimal choice on NII activities (i.e., $n_{m}=n_{m}^{*}$ and $n_{r}=n_{r}^{*}$ ) and isolate the implication of charter value on banking risks alone. 
In the extended model, the bank is also subject to a random shock $-z A$ to equity ${ }^{16}$, where $z$ follows a Bernoulli Distribution:

$$
z= \begin{cases}\epsilon, & \text { with probability } 1-p \\ 0, & \text { with probability } p\end{cases}
$$

One interpretation of shock $z$ is an operational risk shock. The likelihood that the bank is affected by the random shock $z$ depends on the intensity of its monitoring. The more intense the monitoring activity (high monitoring cost), the lower the likelihood that it will be affected by shocks to equity. The monitoring or risk management cost is given by:

$$
C(p)=-\frac{1}{2} b p^{2} A
$$

where $C(p)$ is a function of asset size $A$, the probability of the shock $p$, and a constant $b$. A banks is therefore incentivized to monitor-in order to reduce the expected equity impact from random shock - as long as the marginal monitoring cost does not exceed the marginal impact on bank equity from the random shock.

Also, let $V$ denote the continuation value of bank equity $V$. Other interpretations of $V$ can be the charter value, discounted future profits, or the market value of equity (see Freixas and Rochet 2008, Chapter 3.5). For tractability, we assume that $V$ is exogenously given. ${ }^{17}$

\section{New Objective Function}

The bank's new objective function ${ }^{18}$ is then given by:

$$
\max _{p} \mathbf{E}(\widetilde{\Pi}+E-z A)-\frac{b p^{2} A}{2}+q V,
$$

subject to the balance sheet constraint $L+N_{r}+N_{m}=D+E$. We then normalize the bank's new objective function by asset $A$ and take expectations. The normalized objective function is then given by

\footnotetext{
16 Therefore, there are two sources of randomness in the extended model. The first one is the randomness to asset returns $\tilde{r}_{L}, \tilde{r}_{m}$, and $\tilde{r}_{r}$, which follow a normal distribution as explained earlier. At optimal levels of $n_{m}$ and $n_{r}$, the expected returns are fixed while the actual returns remain random. The second source of randomness is a shock $z$ to bank equity. In the extension, a bank's only choice variable is the probability of the equity shock $z$.

${ }^{17}$ In this stylized model, we do not endogenize the continuation value of equity $V$, as it is not crucial for the derivation of the analytical relationships between bank profitability and financial stability. One could potentially extend the model to a dynamic setting where $V$ will depend on the entry cost of banks.

${ }^{18}$ With limited liability, there is a threshold $\widehat{V}$ (charter value) below which banks engages in risk-taking behavior, as the low charter value is not sufficient to discipline them (Freixas and Rochet 2008, Chapter 3.5). This mechanism is not our focus, as the empirical evidence is largely in favor of the mechanism that charter value defers risk taking (see, for example, Keeley 1990; and Berger, Klapper, and Turk-Ariss 2009), which is captured in our modeling framework.
} 


$$
\max _{p} \mu_{\pi}^{*}+e-\epsilon(1-p)-\frac{b p^{2}}{2}+q e v
$$

where $v=\frac{V}{E}=$ Price/Book Ratio and $e=\frac{E}{A}$ captures the inverse of leverage.

Since the bank is subject to a new equity shock, the bank's survival profitability is modified to $q^{\prime}$, reflecting the Bernoulli Distribution of shock $z$ :

$$
\begin{array}{rc}
q^{\prime}= & \operatorname{Prob}(\widetilde{\pi}+e-z \geq 0) \\
= & p \cdot \operatorname{Prob}(\widetilde{\pi}+e \geq 0)+(1-p) \cdot \operatorname{Prob}(\widetilde{\pi}+e \geq \epsilon) \\
& =p\left[\Phi\left(\frac{\mu_{\pi}+e}{\sigma_{\pi}}\right)-\Phi\left(\frac{\mu_{\pi}+e-\epsilon}{\sigma_{\pi}}\right)\right]+\Phi\left(\frac{\mu_{\pi}+e-\epsilon}{\sigma_{\pi}}\right) .
\end{array}
$$

Bank idiosyncratic risk measures can also be modified to account for the new equity shock:

$$
\begin{gathered}
E D F^{\prime} \equiv 1-q^{\prime}=\operatorname{Prob}(\widetilde{\pi}+e-z<0) \\
\operatorname{Prob}(|\operatorname{Loss}| \geq \operatorname{VaR})=\operatorname{Prob}\left(-\widetilde{\pi}-e+z \geq \operatorname{VaR}^{\prime}\right)=0.05 .
\end{gathered}
$$

The optimal shock probability $p^{*}$ is then given by the first order condition with respect to $p$ :

$$
p^{*}=\frac{\epsilon+\left[\Phi\left(\frac{\mu_{\pi}^{*}+e}{\sigma_{\pi}^{*}}\right)-\Phi\left(\frac{\mu_{\pi}^{*}+e-\epsilon}{\sigma_{\pi}^{*}}\right)\right] e v}{b}
$$

It is interesting to note that $p^{*}$ is positively related to the price-to-book ratio $v$, and the inverse of leverage $e$. Recall that $p^{*}$ is the probability that the equity impact of shock $z$ is zero (or minimum), and a higher $p^{*}$ is associated with more intense monitoring or higher monitoring costs. One interpretation is that rising price-to-book values or falling leverage (higher equity) incentivizes banks to monitor and to reduce the equity impact of shocks. Based on these consideration, we derive two propositions that underpin the analytical relationships between idiosyncratic risks and the price-to-book ratio, and between idiosyncratic risks and bank leverage.

\section{Risks and the Price-to-Book Ratio}

Proposition 4: Bank idiosyncratic risks measured by EDF' and VaR' are decreasing in the price-to-book ratio $v$ :

$$
\frac{\partial E D F^{\prime}}{\partial v}<0, \quad \frac{\partial V a R^{\prime}}{\partial v}<0
$$

Proof: See Appendix II.

The intuition for the negative relationship between bank idiosyncratic risks and the price-tobook value, $v$, is that higher charter value or long-term profits (captured by $v$ ) deters risktaking behavior of banks. A bank is only able to retain its charter value if it survives at the 
end of the period. Therefore, the higher the $v$, the higher the incentive for banks to reduce risk-taking and avoid potential bankruptcy. This finding is consistent with that of Keeley (1990) and subsequent papers (e.g., Besanko and Thakor 1993; Matutes and Vives 2000; Repullo 2004) that charter value provides incentive for prudence. ${ }^{19}$

\section{Risks and Leverage}

We can also derive that a higher equity to asset ratio, or lower leverage, will reduce bank idiosyncratic risks.

Proposition 5: Bank idiosyncratic risks measured by EDF' and VaR' are decreasing in e (increasing in leverage $\frac{1}{e}$ )

$$
\frac{\partial E D F^{\prime}}{\partial e}<0, \frac{\partial V a R^{\prime}}{\partial e}<0
$$

\section{Proof: See Appendix II.}

Higher equity-to-asset ratio $e$ implies more "skin in the game" for banks, and thus they will have higher incentives to monitor and reduce risk-taking behaviors to avoid defaults. As discussed earlier, this is reflected by the fact that $p$, the probability of no equity shock (a choice variable to the bank), is negatively related to $e$, as in $p^{*}=\frac{\epsilon+\left[\Phi\left(\frac{\mu_{\pi}^{*}+e}{\sigma_{\pi}^{*}}\right)-\Phi\left(\frac{\mu_{\pi}^{*}+e-\epsilon}{\sigma_{\pi}^{*}}\right)\right] e v}{b}$. Additionally, higher equity increases the buffer against negative shocks for banks, which reduce bank risks mechanically through accounting relationships in bank balance sheets. ${ }^{20}$

\footnotetext{
${ }^{19}$ Some papers that internalize borrowers' decisions argue that if lower profitability results from lower interest rate margins, reducing credit rationing in the loan market will improve the average quality of loan applicants, which ultimately translates to lower bank risks (Boyd and De Nicolo 2005; Stiglitz and Weiss 1981). Given that interest rates were very low in our 2004-2017 sample period, it is reasonable to abstract from the credit rationing channel. Instead, we focus on the equity buffer channel and the charter value channel of bank profitability in our stylized theoretical model.

${ }^{20}$ It should be noted that the relationship between idiosyncratic risk and leverage also holds in the simple baseline model. The intuition is that higher equity leads to higher buffers against negative shocks. In the extended model, the channels through which leverage affects idiosyncratic risks are richer, as they not only pertain to equity buffers, but also to the charter value of banks and bank incentives to monitor. For completion, we also provide a proof on the negative relationship between idiosyncratic risk and leverage in the simple baseline model (Corollary 1) in the Appendix II.
} 


\section{STYlized FACTS ANd EMPIRICAL METHOdOLOGY}

\section{A. Key Variables}

We consider a sample of 431 publicly-traded banks in our empirical analysis. The sample includes all public banks in the U.S. and developed Europe, and all other Global Systemically Important Banks (GSIBs). ${ }^{21}$ The sample period spans from 2004 to 2017 and the data source is S\&P Global Market Intelligence's SNL database. ${ }^{22}$

\section{Profitability Measures}

Five profitability measures are considered in the empirical analysis: ROAA, ROAE, riskadjusted ROAA, risk-adjusted ROAE, and the price-to-book ratio. ${ }^{23}$ The risk-adjusted profitability measures are computed as the ratio of headline profitability measures (ROAA or ROAE) and their standard deviation for the sample period (2004 to 2017) for each bank. The price-to-book ratio is the ratio of the market value of equity (share price) and the book value of equity, which is often used as a proxy for expected profitability (or charter value).

\section{Financial Stability Measures}

Financial stability is captured by three systemic and idiosyncratic risk measures. Systemic risk is measured by the delta $\triangle \mathrm{CoVaR}$ (Adrian and Brunnermeier 2016), while idiosyncratic risk is measured by the five percent VaR and Moody's EDF. ${ }^{24}$

\section{Idiosyncratic Risk Measures}

Idiosyncratic risk is measured by two market-based risk measures: historical VaR based on annualized daily equity return at 5 percent and Moody's EDF.

The five percent VaR is computed as the lowest five percent quantile of daily equity returns in a particular year. Moody's EDF is a forward-looking measure of actual probability of default of a bank over a specified period of time (one year in this application). According to

\footnotetext{
${ }^{21}$ Among the publicly traded banks, 308 are from the U.S. and 115 are from developed Europe. In addition, the sample includes the eight GSIBs from outside the U.S. and the Europe. The average asset size for U.S. banks, European banks, and GSIBs are \$53 billion, \$274 billion, and \$1710 billion, respectively. The GSIB list follows the classification by the Financial Stability Board (FSB) in 2017. http://www.fsb.org/2017/11/2017-list-ofglobal-systemically-important-banks-g-sibs/

${ }^{22}$ For sources and definitions of the variables, see Appendix III.

${ }^{23}$ The choice of the profitability measures is motived by our theoretical model. ROAA and ROAE are empirical proxies for per-period profit $\left(\mu_{\pi}\right)$, and the price to book ratio is an empirical proxy for chart value or discounted future profits $(V)$. In addition, we are interested in analyzing risk-adjusted ROAA and ROAE measures.

${ }^{24}$ Similarly, the choice of idiosyncratic risk measures is motivated by the theoretical model. The empirical VaR and EDF map directly to the risk measures (VaR and EDF) in the theoretical framework. We also consider an established systemic risk measure $\triangle \mathrm{CoVaR}$ that was suggested by Adrian and Brunnermeier (2016).
}

(continued...) 
the Moody's EDF model, a bank defaults when the market value of its assets falls below its liabilities. $^{25}$

\section{Systemic Risk Measure}

Following Adrian and Brunnermeier (2016), the $\triangle \mathrm{CoVaR}$ is estimated using quantile regression on weekly data ${ }^{26}$ :

$$
\begin{gathered}
X_{t}^{i}=\alpha_{q}^{i}+\gamma_{q}^{i} M_{t-1}+\varepsilon_{q, t}^{i}, \\
X_{t}^{\text {System } \mid i}=\alpha_{q}^{\text {System } \mid i}+\gamma_{q}^{\text {System } \mid i} M_{t-1}+\beta_{q}^{\text {System } \mid i} X_{t}^{i}+\varepsilon_{q, t,}^{\text {System } \mid i}
\end{gathered}
$$

where $X_{t}^{i}$ denotes the weekly equity return of bank $i, X_{t}^{\text {System|i }}$ the weekly system equity return conditional on bank $i$, and $M_{t}$ the list of state variables. We use $q$ to denote the $q$ th quantile. We then use the predicted values from these regressions to obtain $V a R$ and CoVaR conditional on state variables:

$$
\begin{gathered}
\operatorname{VaR}{ }_{q, t}^{i}=\hat{\alpha}_{q}^{i}+\hat{\gamma}_{q}^{i} M_{t-1}, \\
\operatorname{CoVaR}_{q, t}^{i}=\hat{\alpha}_{q}^{\text {System } \mid i}+\hat{\gamma}_{q}^{\text {System } \mid i} M_{t-1}+\hat{\beta}_{q}^{\text {System } \mid i} \operatorname{VaR}{ }_{q, t .}^{i}
\end{gathered}
$$

Finally, we compute $\Delta \operatorname{CoVaR} R_{q, t}^{i}$ for each bank as the difference between the $\mathrm{q}^{\text {th }}$ percentile CoVaR and the median CoVaR:

$$
\Delta \operatorname{CoVaR} R_{q, t}^{i}=\operatorname{CoVaR}_{q, t}^{i}-\operatorname{CoVaR}_{50, t}^{i}=\hat{\beta}_{q}^{\text {System } \mid i}\left(\operatorname{VaR}_{q, t}^{i}-\operatorname{VaR}_{50, t}^{i}\right) .
$$

In this paper, we consider the $5^{\text {th }}$ percentile $\Delta \mathrm{CoVaR}$ in the empirical analysis. For European banks, Euro Stoxx bank returns were used to capture financial sector returns, while S\&P 500 financial index returns were used for U.S. banks and other GSIBs.

We consider a set of state variables in the quantile regression estimations, including interest rates, term structure of interest rates, liquidity risk, credit risk, market returns, market volatility, and excess return of the financial sector over the real estate sector. For the most part, U.S.-specific state variables were used to construct the $\Delta \mathrm{CoVaR}$ for U.S. banks and other GSIBs, ${ }^{27}$ while Europe-specific state variables were applied to European banks. The exception was credit risk and VIX measures, which were used in both cases.

The following set of state variables were used in the estimation: (i) interest rates, measured by the change in 3-month German bond yields, and the change in 3-month T-bill rates; (ii)

\footnotetext{
${ }^{25}$ See Moody's Analytics at https://www.moodysanalytics.com for details on constructing EDFs.

${ }^{26}$ For ease of illustration, we follow the same notation as in Adrian and Brunnermeier (2016).

${ }^{27}$ Similar to López-Espinosa et al. (2012), we use the set of state variables sampled from the U.S. market as common conditional variables for other GSIBs.
} 
term structure of interest rates, measured by the change in the spread between 10-year and 3month German government bond yields, and the change in the spread between 10-year and 3month T-bill rates; (iii) liquidity risk, measured by the change in the difference between 3month Euribor (Euro Interbank Offered Rate) and 3-month Germany bond yields, and the change in the difference between 3-month LIBOR and 3-month secondary market T-bill rates; (iv) credit risk, measured by the change in credit spreads between Moody's Baa-rated bonds and the 10-year Treasury rates; (v) market returns from the Euro Stoxx 50 and S\&P 500 indices; (vi) market volatility, measured by the change in the VIX index; and (viii) excess return of the financial sector over the real estate sector, measured by the difference between the Euro Stoxx banks index returns and the MSCI Europe real estate index returns, and the difference between the S\&P 500 financials index returns and the Dow Jones U.S. real estate index..$^{28}$

\section{Bank Business Models and Characteristics}

Bank business models are captured by four variables in the analysis. First, to measure the reliance of banks on NII we consider the share of NII to revenue. Second, the LTA ratio is used as a proxy for retail vs. wholesale business models for banks. Third, the deposit-toliability ratio is used to capture banks' reliance on wholesale funding. Fourth, the asset-toequity ratio is used to measure the extent of leverage. These four business model variables capture both returns and asset allocation of banks, and both the asset and the liabilities sides of bank balance sheets. The four variables are examined in detail in the analysis on the determinants of risks.

Several variables on bank characteristics are controlled for in the empirical analysis, including solvency, measured by the Tier 1 capital ratio; asset quality, captured by the problem loans ratio; and efficiency, captured by cost-to-income and cost of funds ratios. The cost-to-income ratio is measured by the ratio of operating expense to operating income and is a standard measure of operating efficiency (Borio, Gambacorta, Hofmann 2017; IMF 2017). The cost of funds ratio is captured by the interest incurred on liabilities as a percent of average noninterest-bearing deposits and interest-bearing liabilities.

In addition, the Lerner index was constructed to capture the market power or mark-up of banks. Following the specification in Berger, Klapper, and Turk-Ariss (2009), the Lerner Index for bank $i$ was constructed as $L_{i t}=\frac{P_{i t}-M C_{i t}}{P_{i t}}$, where $P_{i t}$ is the price of assets, measured by the ratio of total revenue to total assets, and $M C_{i t}$ is the marginal cost of total assets. The higher the value of the Lerner index, the easier it is for a bank to charge over its marginal costs, and therefore the greater its mark-up or market power.

\footnotetext{
${ }^{28}$ As a robustness check, we also consider a version of the $\Delta \mathrm{CoVaR}$ estimation that controls for state variables based on world variables, in addition to regional ones. In this case, the financial sector return was measured by the return of the MSCI world financial index, the market return was captured by the MSCI world index return, and the excess return was measured by the difference between the MSCI world financial index returns and the MSCI world real estate index returns. The results are found to be very similar. For the rest of the paper, we focus on the $\triangle \mathrm{CoVaR}$ analysis based on region-specific state variables.
} 
The marginal cost of total assets for bank $i$ at time $t, M C_{i t}$, is computed as $M C_{i t}=\frac{\operatorname{cost}_{i t}}{Q_{i t}}\left[\beta_{1}+\beta_{2} \ln Q_{i t}+\sum_{k=1}^{3} \phi_{k} \ln W_{k, i t}\right]$, where $W_{1, k t}$ is the ratio of personnel expense to total assets and a proxy for the input price of labor, $W_{2, k t}$ is the ratio of interest expense to total deposits and a proxy for the input price of funds, and $W_{3, k t}$ is the ratio of other operating and administrative expenses to total assets and captures the input price of fixed capital. ${ }^{29} Q_{i t}$ and $\operatorname{cost}_{i t}$ capture total assets and total costs, respectively. Furthermore, the coefficients $\beta_{1}, \beta_{2}$, and $\phi_{k}$ are estimated from the following cost equation:

$\ln \operatorname{cost}_{i t}=\beta_{0}+\beta_{1} \ln Q_{i t}+\frac{\beta_{2}}{2} \ln Q_{i t}^{2}+\sum_{k=1}^{3} \gamma_{k t} \ln W_{k, i t}+\sum_{k=1}^{3} \phi_{k} \ln Q_{i t} \ln W_{k, i t}+$ $\sum_{k=1}^{3} \sum_{j=1}^{3} \ln W_{k, i t} \ln W_{j, i t}+\epsilon_{i t}$.

As noted in the literature, the Lerner index has several advantages over alternative measures of market competition and concentration. First, the Lerner index can be computed at the bank level, without relying on precise definitions of the geographic product markets (Anginer, Demirgüç-Kunt, and Zhu 2014). For the international-oriented banks in our sample, it is particularly difficult to define geographic markets as they often operate in number of jurisdictions and product markets. Second, the Lerner index measures a bank's pricing power or mark-up and better captures the theoretical concept of bank franchise value (Beck, De Jonghe, and Schepens 2013). In addition, the Lerner index utilizes information on both the asset and liability sides of bank balance sheets, as it captures both profits (generated with bank assets) and costs of bank operations (Anginer, Demirgüç-Kunt, and Zhu 2014).

\section{Policy Measures and Cyclical Variables.}

For the empirical analysis, we control for both monetary and fiscal policy measures. Monetary policy is measured by 3-month short-term interest rates (OECD) and central banks' claims on financial institutions (IMF IFS). Fiscal policy is measured by the ratio of government structural balances to potential GDP, to proxy the fiscal stance (IMF WEO). We use GDP growth as a proxy for cyclical conditions in the economy.

\section{B. Stylized Facts}

Bank profitability, measured by ROAA, ROAE, and price-to-book ratio, all declined sharply during the 2007-2009 GFC (Figure 3). In general, U.S. banks have recovered faster than European banks post-crisis partly because European banks experienced another sharp decline in book profitability and price-to-book ratios during the 2012-2014 European Sovereign Debt Crisis. Interestingly, while U.S. banks' book return (ROAA and ROAE) were not affected by the European Sovereign Debt Crisis, their price-to-book ratio experienced a sizable drop. This suggests that while the actual impact of the European crisis on book profitability was regional, it influenced investor's perception of banks' capacity to generate future profits

\footnotetext{
${ }^{29}$ Note that $W_{2, k t}$ reflects market power in the deposit market. Alternatively, the Lerner index could be computed using the marginal cost estimation for bank loans, which requires a measure of the risk premium based on confidential supervisory data (Jiménez, Lopez, and Saurina 2013).
} 
globally. It should be noted that none of the profitability measures have returned to pre-crisis levels. ${ }^{30}$

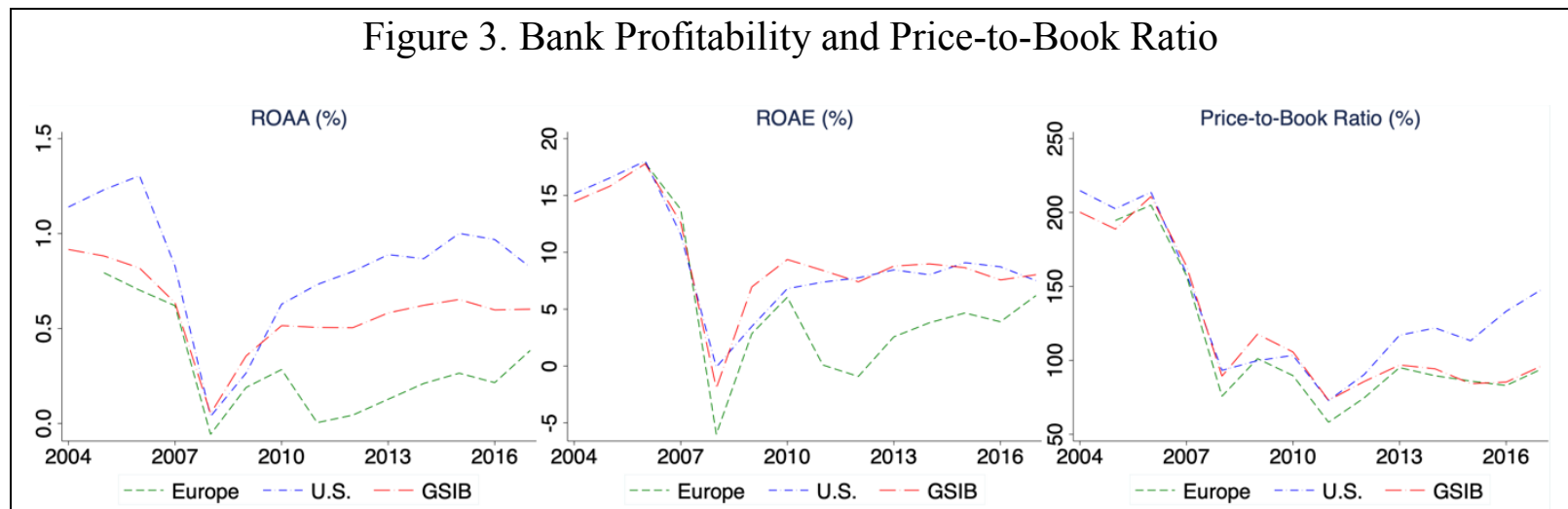

Note: See Appendix III for sources and definitions of the variables. The figures are weighted using asset share for each group of banks. The green, blue, and red lines denote European banks, U.S. banks, and Global Systemically Important Banks (GSIBs), respectively.

Sources: S\&P Global Market Intelligence's SNL database and IMF staff calculations.

For systemic and idiosyncratic risk measures, we also observe a clear impact from the GFC and the European Sovereign Debt Crisis, where risks became elevated (Figure 4). For systemic risk measured by the $\Delta \mathrm{CoVaR}, \mathrm{U}$.S. banks tend to have a higher contribution to systemic risk, compared with European banks. ${ }^{31}$ For idiosyncratic risks measured by the VaR and the EDF, they appeared elevated for U.S. banks during the 2007-2009 GFC, but were overtaken by European banks during the 2012-2014 European Sovereign Debt Crisis.

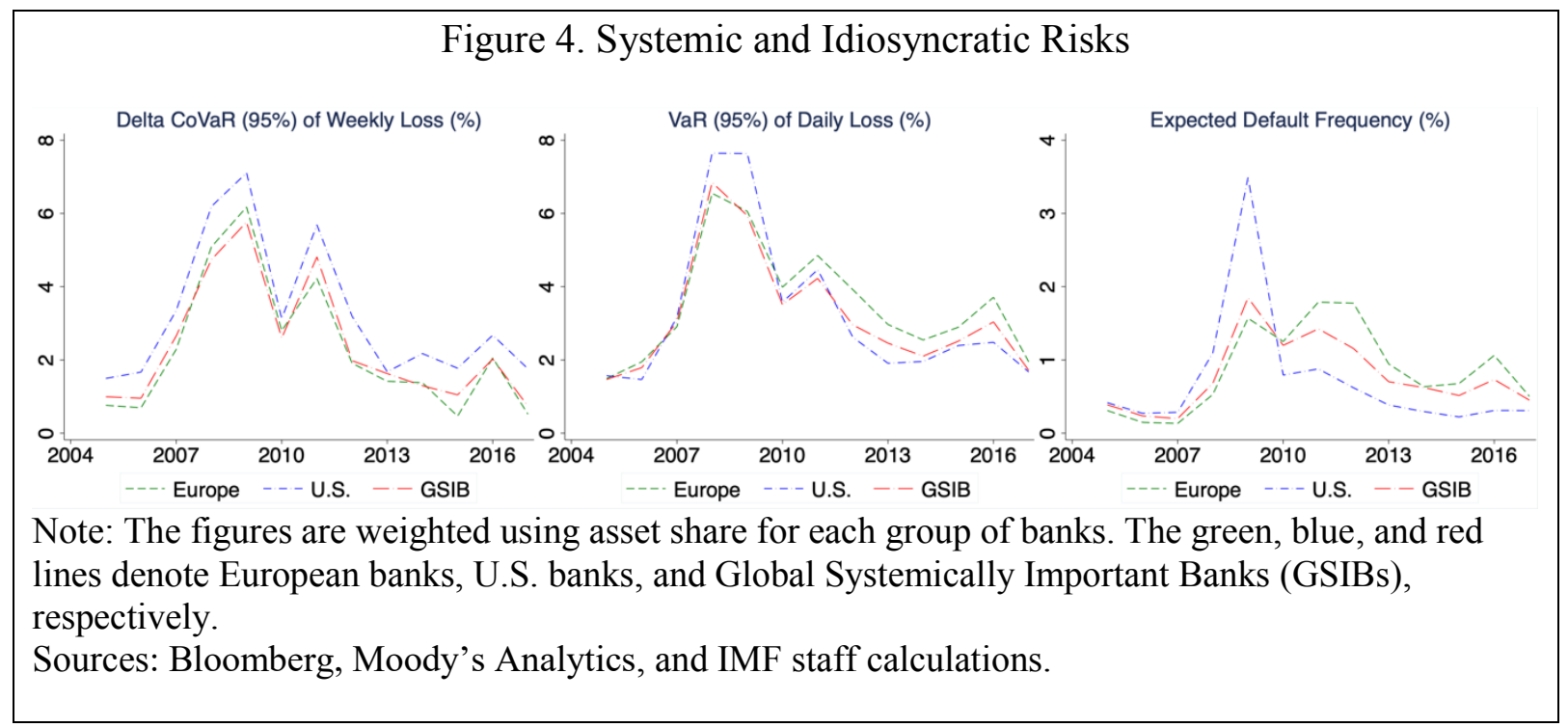

\footnotetext{
${ }^{30}$ Risk-adjusted ROAA and ROAE display similar dynamics.

${ }^{31}$ It should be noted that both $\triangle \mathrm{CoVaR}$ measures (with regional and global state variables) show that U.S. banks tend to have a higher contribution to systemic risks, in part because equity returns in the U.S. are more correlated with global equity returns.
} 
On bank characteristics, U.S. banks tend to have higher LTA and deposit-to-liability ratios during the 2004-2017 sample period (Figure 5). As expected, GSIBs have the lowest LTA ratios, as a high proportion of their balance sheets are devoted to investment banking and other non-traditional banking business. ${ }^{32}$ In general, LTA ratios have increased for banks since the crisis. While the NII share has declined since the crisis, it has stabilized more recently. European banks appear to have higher leverage and higher problem loan ratios compared with U.S. banks and GSIBs, despite a decline since the peak of the crisis. The Tier 1 ratio has risen markedly for banks since the crisis, in part due to tighter regulations. More recently, cost efficiency, measured by the cost-to-income ratio, has improved for GSIBs and U.S. banks. Similarly, funding costs have declined for banks, with U.S. banks enjoying the lowest cost of funds on average. Finally, the Lerner index suggests that U.S. banks have higher pricing power compared with European banks and GSIBs.

Figure 5. Bank Business Models and Characteristics
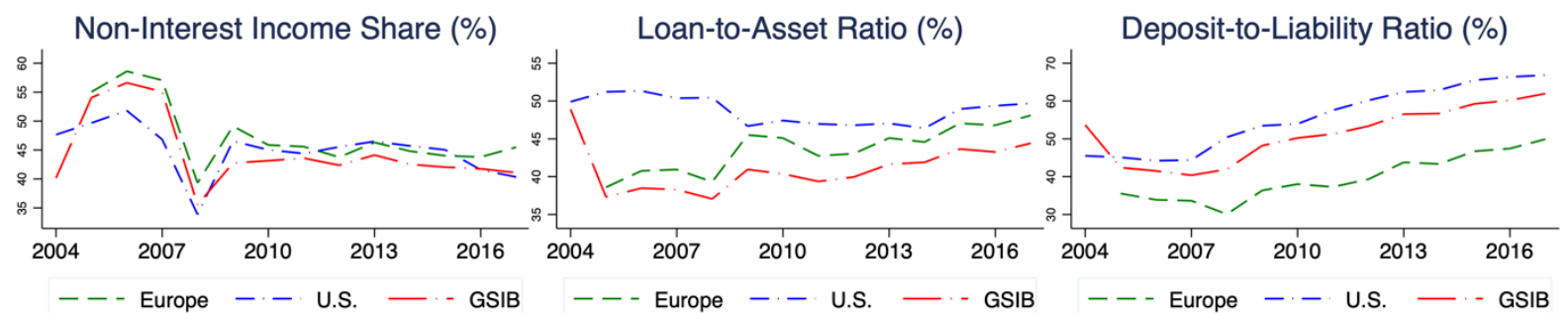

Tier 1 Ratio (\%)

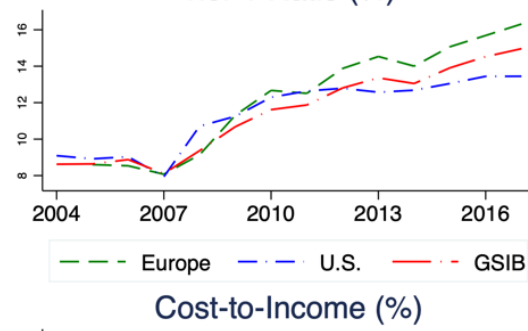

Leverage Ratio

Problem Loans Ratio (\%)
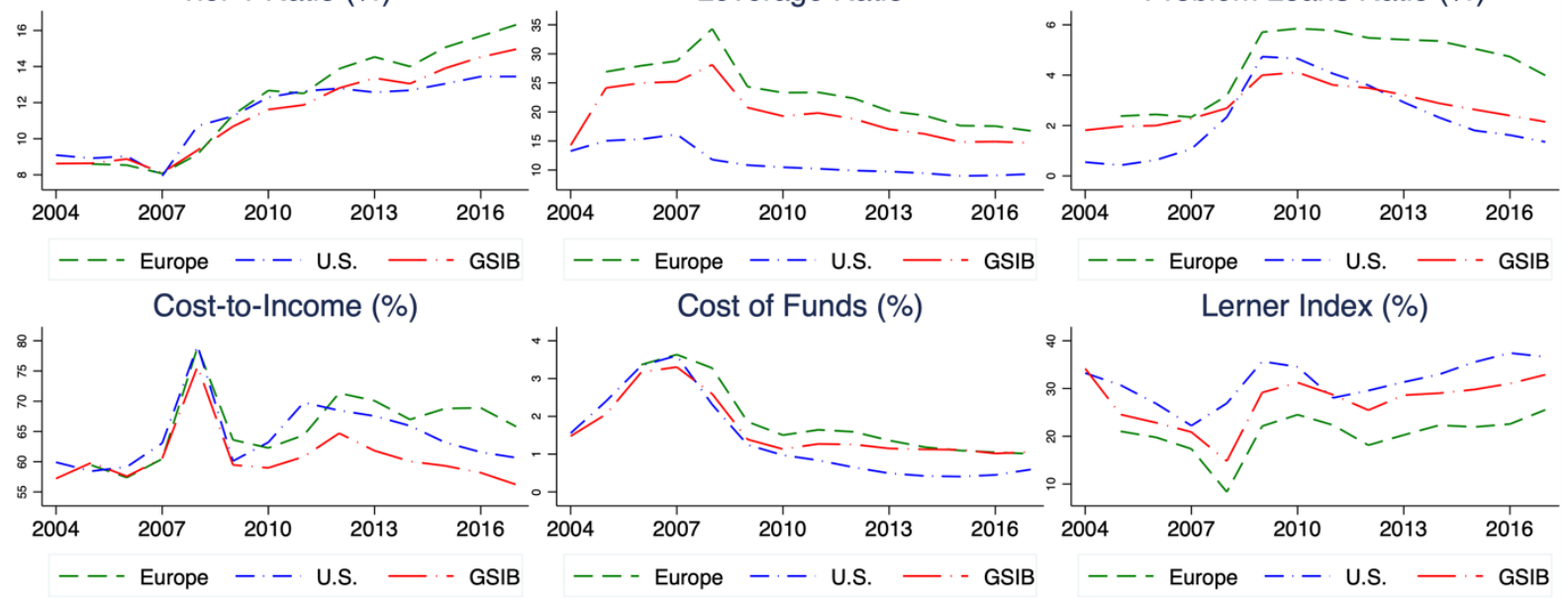

Cost of Funds (\%)
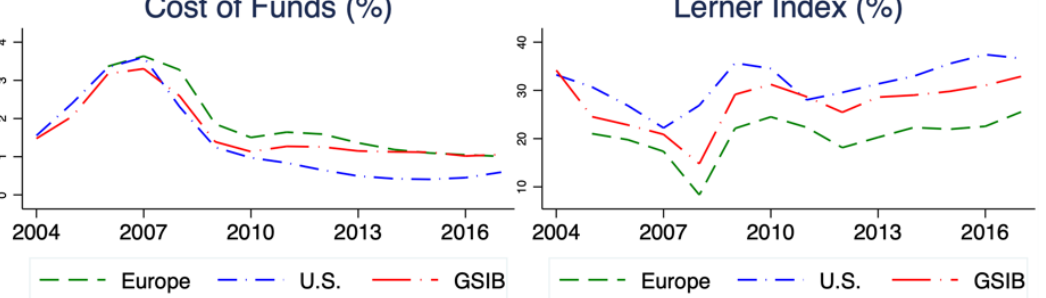

Note: See Appendix III for sources and definitions of the variables. The figures are weighted using asset share for each group of banks. The green, blue, and red lines denote European banks, U.S. banks, and Global Systemically Important Banks (GSIBs), respectively. The leverage ratio is constructed as the ratio of asset to equity.

Sources: S\&P Global Market Intelligence's SNL database and IMF staff calculations.

${ }^{32}$ Average LTA ratios for European, U.S., and Asian GSIBs are 43\%, 32\%, and 48\%, respectively, in 2017. Similarly, average NII ratios for European, U.S., and Asian GSIBs are 48\%, 58\% and 39\%, respectively, suggesting that U.S. GSIBs are more involved in investment banking and other non-traditional banking business. 


\section{Hypotheses and Empirical Methodology}

Based on our stylized theoretical model, we derive four testable hypotheses to be examined empirically. The relationship between idiosyncratic risks and bank profitability and that between profitability and its determinants are directly based on the five propositions from the theoretical model. Furthermore, we are interested in understanding if the predicted relationship between bank profitability and idiosyncratic risks could be extended to systemic risks empirically.

Hypothesis 1: Low profitability is associated with high idiosyncratic risks (Proposition 1 \& 4) and high contribution to systemic risks.

Hypothesis 2: High NII share is associated with high idiosyncratic risks (Proposition 2) and high contribution to systemic risks for less retail-oriented banks. ${ }^{33}$

Hypothesis 3: High leverage is associated with high idiosyncratic risks (Proposition 5) and high contribution to systemic risks.

Hypothesis 4: High NPL ratio, funding, and operating costs are associated with low profitability (Proposition 3).

The first three hypotheses relate to bank business models and the impact of the source of bank profitability on risks, and the last hypothesis relates to determinants of bank profitability. In addition to the four hypotheses, we are also interested in examining the effect of the Lerner index (market power) and the reliance on wholesale funding on idiosyncratic and systemic risks.

The main empirical approach to examine the four hypotheses on bank profitability, financial stability, and business models was a panel regression setup that controls for business models, bank characteristics, as well as policy variables and cyclical conditions in the economy. It was estimated with the Arellano-Bover/Blundell-Bond linear dynamic panel-data estimator with robust standard errors ${ }^{34}$, specified as follows:

$$
Y_{k, j, t}=\delta Y_{k, j, t-1}+\vartheta_{k}+\phi^{\prime} X_{k, j, t}+\Lambda^{\prime} M_{j, t}+\varepsilon_{k, j, t}
$$

\footnotetext{
${ }^{33}$ Systemic risk measures, like the $\Delta \mathrm{CoVaR}$, often capture the contribution of individual financial institutions to the fragility of the entire financial system, and the extent to which individual financial institution's equity returns co-move with the rest of the market or $\beta$ (Adrian and Brunnermeier 2016). Furthermore, banks with higher correlation with system equity returns have higher exposure to systemic events (e.g., market-wide equity or asset loss) and are more likely to contribute to systemic risks (see Acharya et al. 2017; and Meiselman, Nagel, and Purnanandam 2018). Therefore, it is not unreasonable to postulate that systemic risk measures are closely linked with market-based NII activities.

${ }^{34}$ A dynamic panel regression is specified due to the persistence in systemic and idiosyncratic risks. The Arellano-Bover/Blundell-Bond system estimator is an extension of the Arellano-Bond estimator that accommodates large autoregressive parameters and a large ratio of the variance of the panel-level effect to the variance of idiosyncratic error. The Arellano-Bover/Blundell-Bond system estimator is designed for datasets with many panels and few periods, which is the case for our dataset. An alternative fixed-effect static panel was specified as a robustness check and the results were found to be broadly similar.
} 
where $Y_{k, j, t}$ captures either risks or profitability for bank $k$, headquartered in country $j$ at time $t$. To take into account bank-specific conditions, we include a set of bank-fixed effects $\left(\vartheta_{k}\right)$ and a vector of (time-varying) bank-specific indicators $X_{k, j, t}$.

We consider two groups of panel regression estimations. In the first group, we examine the determinants of financial stability or risks, measured by the $\mathrm{VaR}$, the EDF, and the $\Delta \mathrm{CoVaR}$ $\left(Y_{k, j, t}\right)$. Key bank-specific variables $\left(X_{k, j, t}\right)$ include bank profitability, the share of NII, and the interaction term between NII and the LTA ratio. We also consider the bank-specific problem loan ratio, leverage, and the Lerner index. In addition, we control for policy and cyclical variables $\left(M_{j, t}\right)$, capturing monetary policy (short-term interest rates), fiscal policy (government structural balance), and GDP growth. This first group of estimations are used to empirically test the first three hypotheses derived from the theoretical model ${ }^{35}$.

In the second group of estimations, we examine the determinants of bank profitability and apply a similar dynamic panel regression specification as above. In this case, $Y_{k, j, t}$ captures measures of bank profitability, including ROAA, ROAE, risk-adjusted profitability, and the price-to-book ratio. We control for a number of bank-specific variables, $X_{k, j, t}$, including the problem loan ratio, cost efficiency (measured by the cost-to-income ratio), as well as the funding costs of banks. In addition, we capture a similar set of policy and cyclical variables $\left(M_{j, t}\right)$. The second group of estimations are applied to test hypothesis 4 empirically ${ }^{36}$.

\section{EMPIRICAL Findings ON The Determinants of Risks AND Profitability}

\section{A. Profitability, Business Models, and Financial Stability}

This subsection quantifies the impact of profitability on financial stability using bank-level data for publicly traded U.S., European banks, and Global Systemically Important Banks (GSIBs). As mentioned earlier, financial stability is measured by both idiosyncratic and systemic risks. Idiosyncratic risk is captured by the VaR (5 percent) and Moody's EDF, and systemic risk is captured by the $\Delta \mathrm{CoVaR}$.

\section{Idiosyncratic risk}

As predicted by our stylized theoretical model in Section II, empirical results over the 20042017 sample period reveal that profitability (ROAA) and the price-to-book ratio (charter value) are negatively associated with banks' idiosyncratic risk, measured by VaR (Table 1),

\footnotetext{
${ }^{35}$ We do not divide our sample into pre-crisis (2004-2007) and post-crisis (2008-2017) sub-periods due to data limitation. The dynamic panel regression requires the third or deeper lags as instruments, which leaves us with only 2007's observations at best for a pre-crisis analysis.

36 For the second group of regressions, we do not include variables of NII because the relation between bank business model and profitability is not our focus (see the appendix for a brief review on related literature). Instead, we emphasize how the business model (NII activities) affect bank idiosyncratic and systemic risks.
} 
confirming hypothesis 1 . As banks' book profitability or charter value improves, they have more "skin in the game," and they are less willing to engage in risk-taking behavior. This finding suggests that, on average, the charter value channel dominates as higher profits and consequently higher capital is associated with less risk-taking by banks. The effect of profitability on VaR is also economically significant. A one standard deviation increase in ROAA, for instance, is associated with a 0.64 percentage point decrease in VaR, or about a quarter of the median VaR (2.57 percent). Similarly, a one standard deviation rise in the price-to-book ratio is associated with a 0.59 percentage point decline in $\mathrm{VaR}$, which is also sizable.

\begin{tabular}{|c|c|c|c|c|c|c|}
\hline \multicolumn{7}{|c|}{ Table 1. Empirical Results: Determinants of Idiosyncratic Risk (VaR) } \\
\hline & (1) & (2) & (3) & (4) & (5) & (6) \\
\hline VARIABLES & VaR & VaR & VaR & VaR & VaR & VaR \\
\hline ROAA (\%) & $\begin{array}{c}-0.841 * * * \\
(0.150)\end{array}$ & & $\begin{array}{c}-1.024 * * * \\
(0.153)\end{array}$ & & $\begin{array}{c}-1.036 * * * \\
(0.161)\end{array}$ & \\
\hline Price-to-Book Ratio (\%) & & $\begin{array}{c}-0.00917^{* * *} \\
(0.00115)\end{array}$ & & $\begin{array}{r}-0.0117^{* * *} \\
(0.00127)\end{array}$ & & $\begin{array}{r}-0.0112 * * * \\
(0.00114)\end{array}$ \\
\hline Non-Interest Income Share (\%) & $\begin{array}{c}0.0120 * \\
(0.00709)\end{array}$ & $\begin{array}{c}0.0127^{*} \\
(0.00720)\end{array}$ & $\begin{array}{c}0.00693 \\
(0.00868)\end{array}$ & $\begin{array}{c}0.00309 \\
(0.00952)\end{array}$ & $\begin{array}{l}\mathbf{0 . 0 2 1 5 * *} \\
(0.00961)\end{array}$ & $\begin{array}{l}-0.00353 \\
(0.00823)\end{array}$ \\
\hline NII Share (\%) X Loan-to-Asset Ratio (\%) & $\begin{array}{l}-0.000227^{*} \\
(0.000130)\end{array}$ & $\begin{array}{c}-0.000344 * * * \\
(0.000130)\end{array}$ & $\begin{array}{l}-0.000253^{*} \\
(0.000148)\end{array}$ & $\begin{array}{l}-0.000138 \\
(0.000156)\end{array}$ & $\begin{array}{c}-0.000421 * * * \\
(0.000144)\end{array}$ & $\begin{array}{c}-4.18 \mathrm{e}-05 \\
(0.000152)\end{array}$ \\
\hline Tier 1 Ratio (\%) & $\begin{array}{c}-0.0598 * * * \\
(0.0203)\end{array}$ & $\begin{array}{c}-0.107 * * * \\
(0.0201)\end{array}$ & $\begin{array}{c}-0.0417 * * \\
(0.0195)\end{array}$ & $\begin{array}{c}-0.104 * * * \\
(0.0213)\end{array}$ & $\begin{array}{c}-0.0550 * * * \\
(0.0166)\end{array}$ & $\begin{array}{c}-0.0900 * * * \\
(0.0189)\end{array}$ \\
\hline Problem Loans Ratio (\%) & $\begin{array}{c}0.0434 * * \\
(0.0211)\end{array}$ & $\begin{array}{c}0.0479 * * \\
(0.0215)\end{array}$ & $\begin{array}{c}0.0460 * * \\
(0.0180)\end{array}$ & $\begin{array}{c}\mathbf{0 . 0 5 1 4 * * *} \\
(0.0172)\end{array}$ & $\begin{array}{c}\mathbf{0 . 0 5 4 2 * * *} \\
(0.0191)\end{array}$ & $\begin{array}{c}0.0518^{* * *} \\
(0.0187)\end{array}$ \\
\hline Real GDP growth rate (\%) & $\begin{array}{c}-0.229 * * * \\
(0.0267)\end{array}$ & $\begin{array}{c}-0.275 * * * \\
(0.0302)\end{array}$ & $\begin{array}{c}-0.226 * * * \\
(0.0264)\end{array}$ & $\begin{array}{c}-0.280 * * * \\
(0.0291)\end{array}$ & $\begin{array}{c}-0.235 * * * \\
(0.0269)\end{array}$ & $\begin{array}{c}-0.284^{* * *} \\
(0.0286)\end{array}$ \\
\hline ST interest rate (\%) & $\begin{array}{c}0.116 * * * \\
(0.0300)\end{array}$ & $\begin{array}{c}0.108^{* * *} \\
(0.0296)\end{array}$ & $\begin{array}{c}0.180 * * * \\
(0.0184)\end{array}$ & $\begin{array}{c}0.222 * * * \\
(0.0190)\end{array}$ & $\begin{array}{c}0.186 * * * \\
(0.0175)\end{array}$ & $\begin{array}{c}0.226 * * * \\
(0.0164)\end{array}$ \\
\hline Gov Structural Balance/Potential GDP & $\begin{array}{c}-0.107 * * * \\
(0.0179)\end{array}$ & $\begin{array}{c}-0.0835 * * * \\
(0.0192)\end{array}$ & $\begin{array}{c}-0.124 * * * \\
(0.0190)\end{array}$ & $\begin{array}{c}-0.0869 * * * \\
(0.0195)\end{array}$ & $\begin{array}{c}-0.114^{* * *} \\
(0.0188)\end{array}$ & $\begin{array}{c}-0.0735 * * * \\
(0.0179)\end{array}$ \\
\hline Lerner Index (\%) & $\begin{array}{c}-0.0302^{* * *} \\
(0.00925)\end{array}$ & $\begin{array}{c}-0.0444^{* * *} \\
(0.00908)\end{array}$ & & & & \\
\hline Deposit-to-Liability Ratio (\%) & & & $\begin{array}{l}-0.0122^{* *} \\
(0.00479)\end{array}$ & $\begin{array}{l}-0.00983^{*} \\
(0.00558)\end{array}$ & & \\
\hline Leverage Ratio & & & & & $\begin{array}{c}0.0120 \\
(0.00912)\end{array}$ & $\begin{array}{c}0.0317 * * * \\
(0.0119)\end{array}$ \\
\hline Weekly Delta CoVaR = L & $\begin{array}{c}0.266 * * * \\
(0.0371)\end{array}$ & $\begin{array}{c}0.267 * * * \\
(0.0398)\end{array}$ & $\begin{array}{c}\mathbf{0 . 2 7 2} * * * \\
(0.0345)\end{array}$ & $\begin{array}{c}0.331 * * * \\
(0.0372)\end{array}$ & $\begin{array}{c}\mathbf{0 . 2 6 8 * * *} \\
(0.0411)\end{array}$ & $\begin{array}{c}\mathbf{0 . 3 5 1 * * *} \\
(0.0345)\end{array}$ \\
\hline Observations & 3,867 & 3,833 & 3,919 & 3,886 & 3,922 & 3,889 \\
\hline Hansen p-Value & 0.459 & 0.206 & 0.414 & 0.113 & 0.419 & 0.513 \\
\hline
\end{tabular}

In general, a higher NII share is significantly associated with higher VaR. However, the interaction term between the share of NII and the LTA ratio suggests that a higher NII share in retail-oriented banks tends to be associated with a decline in VaR. This empirical finding is consistent with our theoretical prediction that the negative impact from non-interest income is dependent on the value of the LTA ratio, confirming hypothesis 2 . One explanation 
based on our theoretical model is that retail-oriented banks tend to engage in more traditional or fee-based NII activities due to their existing retail client base, instead of more-risky market-based NII activities. Therefore, the marginal effect of NII on bank risks is dependent on the retail orientation of banks, and there could be some diversification benefits for retailoriented banks to move toward traditional NII activities. Our empirical findings, based on a cross-country sample, are consistent with the earlier work on the German banking sector by Kohler (2014), which suggested that diversification into NII activities were more beneficial for retail-oriented banks such as savings and cooperative banks.

Higher market power, as measured by the Lerner index, is associated with lower VaR. One potential explanation is that profitable banks have higher charter value and are therefore less willing to engage in risk-taking behavior (e.g., Keeley 1990; Berger, Klapper, and Turk-Ariss 2009). Higher leverage or lower equity-to-asset ratios are associated with higher VaR, confirming hypothesis 3. Furthermore, a high reliance on wholesale funding (low deposit-toliability ratios) and elevated problem loan ratios tend to be associated with higher idiosyncratic risk as measured by VaR. Finally, a favorable macroeconomic environment, as measured by high GDP growth, is often associated with lower VaR. ${ }^{37}$

The empirical findings based on the other measure of bank-specific idiosyncratic risk, the EDF, is similar. As predicted by the theoretical model, both the ROAA and the price-to-book ratios are negatively associated with the one-year ahead EDF (Table 2), confirming hypothesis 1.

While a high NII ratio is generally associated with a high default probability, there appears to be diversification benefits for retail-oriented banks, confirming hypothesis 2 . As mentioned earlier, one explanation offered by our theoretical model is that retail-oriented banks tend to engage in fee-based NII activities (less risky) due to their existing retail client base, instead of market-based NII activities such as investment banking and securitization (more risky). Our empirical finding on the relationship between default probability and diversification is consistent with earlier work on the U.S. banking sector by DeYoung and Torna (2013).

Similarly, as was the case for $\mathrm{VaR}$, a higher problem loan ratio is associated with higher default probability for banks. There is some evidence that a higher leverage ratio is significantly associated with higher EDF, confirming hypothesis 3. Finally, a favorable macroeconomic environment is associated with declining bank default probabilities.

\footnotetext{
${ }^{37}$ On monetary policy, the empirical result suggests that monetary easing measured by lower short-term interest rate in our sample period from 2004 to 2017 is associated with lower bank-specific idiosyncratic risks, which suggests that the post-crisis monetary policy response by central banks were effective. However, this finding does not bear conclusion on future paths of monetary policy or how central banks should set monetary policy going forward.
} 


\begin{tabular}{|c|c|c|c|c|c|c|}
\hline \multicolumn{7}{|c|}{ Table 2. Empirical Results: Determinants of Idiosyncratic Risk (EDF) } \\
\hline & (1) & (2) & (3) & (4) & (5) & (6) \\
\hline VARIABLES & trEDF & trEDF & trEDF & $\operatorname{trEDF}$ & trEDF & trEDF \\
\hline ROAA (\%) & $\begin{array}{c}-0.218^{* * *} \\
(0.0650)\end{array}$ & & $\begin{array}{c}-0.231 * * * \\
(0.0615)\end{array}$ & & $\begin{array}{c}-0.207 * * * \\
(0.0559)\end{array}$ & \\
\hline Price-to-Book Ratio (\%) & & $\begin{array}{c}-0.000882 * * \\
(0.000416)\end{array}$ & & $\begin{array}{c}-0.000661 * \\
(0.000341)\end{array}$ & & $\begin{array}{c}-0.000206 \\
(0.000350)\end{array}$ \\
\hline Non-Interest Income Share (\%) & $\begin{array}{c}\mathbf{0 . 0 0 6 4 7 * * *} \\
(0.00233)\end{array}$ & $\begin{array}{c}0.0100 * * * \\
(0.00271)\end{array}$ & $\begin{array}{l}\text { 0.00506* } \\
(0.00281)\end{array}$ & $\begin{array}{c}0.00666 * * \\
(0.00332)\end{array}$ & $\begin{array}{c}0.00820 * * * \\
(0.00257)\end{array}$ & $\begin{array}{c}0.00395 \\
(0.00332)\end{array}$ \\
\hline NII Share (\%) X Loan-to-Asset Ratio (\%) & $\begin{array}{c}-0.000127^{* * *} \\
(4.56 \mathrm{e}-05)\end{array}$ & $\begin{array}{c}-0.000187^{* * *} \\
(4.53 e-05)\end{array}$ & $\begin{array}{c}-\mathbf{0 . 0 0 0 1 3 0 * *} \\
(5.10 \mathrm{e}-05)\end{array}$ & $\begin{array}{c}\mathbf{0 . 0 0 0 1 7 2 * * *} \\
(5.45 \mathrm{e}-05)\end{array}$ & $\begin{array}{c}-0.000114^{* *} \\
(5.70 \mathrm{e}-05)\end{array}$ & $\begin{array}{c}-0.000113 * * \\
(5.56 \mathrm{e}-05)\end{array}$ \\
\hline Tier 1 Ratio (\%) & $\begin{array}{l}0.000793 \\
(0.00712)\end{array}$ & $\begin{array}{l}-0.0146 * \\
(0.00748)\end{array}$ & $\begin{array}{c}0.00610 \\
(0.00752)\end{array}$ & $\begin{array}{l}-0.00826 \\
(0.00822)\end{array}$ & $\begin{array}{l}-0.00121 \\
(0.00683)\end{array}$ & $\begin{array}{l}-0.00367 \\
(0.00737)\end{array}$ \\
\hline Problem Loans Ratio (\%) & $\begin{array}{c}0.0303^{* * *} \\
(0.00493)\end{array}$ & $\begin{array}{c}0.0370 * * * \\
(0.00570)\end{array}$ & $\begin{array}{c}0.0294 * * * \\
(0.00499)\end{array}$ & $\begin{array}{c}\mathbf{0 . 0 3 3 8 * * *} \\
(0.00567)\end{array}$ & $\begin{array}{c}\mathbf{0 . 0 2 7 9} * * * \\
(0.00445)\end{array}$ & $\begin{array}{c}0.0366 * * * \\
(0.00546)\end{array}$ \\
\hline Real GDP growth rate (\%) & $\begin{array}{c}-\mathbf{0 . 0 6 2 3} * * * \\
(0.0115)\end{array}$ & $\begin{array}{c}-0.0817 * * * \\
(0.0115)\end{array}$ & $\begin{array}{c}-0.0615 * * * \\
(0.0114)\end{array}$ & $\begin{array}{c}-\mathbf{0 . 0 8 1 2} * * * \\
(0.0115)\end{array}$ & $\begin{array}{c}-0.0608^{* * *} \\
(0.0116)\end{array}$ & $\begin{array}{c}-0.0816 * * * \\
(0.0113)\end{array}$ \\
\hline ST interest rate (\%) & $\begin{array}{c}\mathbf{0 . 0 4 3 8 * * *} \\
(0.0110)\end{array}$ & $\begin{array}{c}\mathbf{0 . 0 4 3 4} * * * \\
(0.0103)\end{array}$ & $\begin{array}{c}\mathbf{0 . 0 4 4 3 * * *} \\
(0.00725)\end{array}$ & $\begin{array}{c}\mathbf{0 . 0 3 5 5 * * *} \\
(0.00672)\end{array}$ & $\begin{array}{c}\mathbf{0 . 0 4 1 4} * * * \\
(0.00669)\end{array}$ & $\begin{array}{c}0.0317 * * * \\
(0.00650)\end{array}$ \\
\hline Gov Structural Balance/Potential GDP & $\begin{array}{c}-0.0513^{* * *} \\
(0.00719)\end{array}$ & $\begin{array}{c}-0.0469 * * * \\
(0.00783)\end{array}$ & $\begin{array}{c}-0.0513 * * * \\
(0.00765)\end{array}$ & $\begin{array}{c}-0.0490 * * * \\
(0.00861)\end{array}$ & $\begin{array}{c}-0.0520 * * * \\
(0.00719)\end{array}$ & $\begin{array}{c}-0.0524 * * * \\
(0.00842)\end{array}$ \\
\hline Lerner Index (\%) & $\begin{array}{c}0.00143 \\
(0.00302)\end{array}$ & $\begin{array}{c}0.00341 \\
(0.00290)\end{array}$ & & & & \\
\hline Deposit-to-Liability Ratio (\%) & & & $\begin{array}{r}-0.000795 \\
(0.00160)\end{array}$ & $\begin{array}{l}-0.00226 \\
(0.00177)\end{array}$ & & \\
\hline Leverage Ratio & & & & & $\begin{array}{r}-0.000684 \\
(0.00180)\end{array}$ & $\begin{array}{c}0.0144^{* * *} \\
(0.00397)\end{array}$ \\
\hline Weekly Delta CoVaR $=\mathrm{L}$ & $\begin{array}{c}0.578 * * * \\
(0.0317)\end{array}$ & $\begin{array}{c}0.623 * * * \\
(0.0333)\end{array}$ & $\begin{array}{c}0.583 * * * \\
(0.0314)\end{array}$ & $\begin{array}{c}0.628 * * * \\
(0.0327)\end{array}$ & $\begin{array}{c}\mathbf{0 . 6 0 1} * * * \\
(0.0303)\end{array}$ & $\begin{array}{c}0.625 * * * \\
(0.0304)\end{array}$ \\
\hline Observations & 2,971 & 2,943 & 3,013 & 2,987 & 3,016 & 2,990 \\
\hline Hansen $p$-Value & 0.401 & 0.414 & 0.367 & 0.203 & 0.351 & 0.370 \\
\hline
\end{tabular}

\section{Systemic Risks}

In addition to bank idiosyncratic risks, we also consider the relationship between bank profitability and systemic risks. Empirical results reveal that profitability (ROAA) and the price-to-book ratios (charter value) are negatively associated with banks' contribution to systemic risk ( $\triangle \mathrm{CoVaR}$; see Table 3 ). As firm's current book profitability or charter value improves, their contribution to systemic risk tend to decline (hypothesis 1). One intuitive explanation for this finding is that, as banks' charter value increases, they engage in less risktaking at the individual bank level, and thereby reducing their systemic risk contribution. While some analysis that examined crisis episodes suggests that high profits in good times could be an indicator of systemic tail risk in bad times (Meiselman, Nagel, and Purnanandam 2018), our results suggest that on average the charter value channel dominates as higher profits and consequently higher capital is associated with less risk-taking by banks when we consider a full sample that embeds both crisis and normal times from 2004 to 2017. 
Like the findings for idiosyncratic risks, a higher share of NII is generally associated with a higher contribution to systemic risks, and there appears to be diversification benefits for retail-oriented banks that move into NII activities (hypothesis 2). There is also evidence that high leverage (hypothesis 3 ) and an over-reliance on wholesale funding are associated with higher systemic risks.

Table 3. Empirical Results: Determinants of the Contribution to Systemic Risk ( $\Delta \mathrm{CoVaR})$

\begin{tabular}{|c|c|c|c|c|c|c|}
\hline VARIABLES & $\begin{array}{l}\text { (1) } \\
\text { covar }\end{array}$ & $\begin{array}{l}\text { (2) } \\
\text { covar }\end{array}$ & $\begin{array}{l}\text { (3) } \\
\text { covar }\end{array}$ & $\begin{array}{l}\text { (4) } \\
\text { covar }\end{array}$ & $\begin{array}{l}\text { (5) } \\
\text { covar }\end{array}$ & $\begin{array}{l}\text { (6) } \\
\text { covar }\end{array}$ \\
\hline ROAA (\%) & $\begin{array}{c}-0.370^{* * *} \\
(0.107)\end{array}$ & & $\begin{array}{c}-0.220^{* * *} \\
(0.0790)\end{array}$ & & $\begin{array}{c}-0.263^{* * *} \\
(0.0805)\end{array}$ & \\
\hline Price-to-Book Ratio (\%) & & $\begin{array}{c}-0.00502^{* * *} \\
(0.00101)\end{array}$ & & $\begin{array}{c}-0.00292 * * * \\
(0.000845)\end{array}$ & & $\begin{array}{c}-0.00348 * * * \\
(0.00117)\end{array}$ \\
\hline Non-Interest Income Share (\%) & $\begin{array}{c}\mathbf{0 . 0 4 3 2 * * *} \\
(0.00899)\end{array}$ & $\begin{array}{c}0.0446 * * * \\
(0.00882)\end{array}$ & $\begin{array}{c}0.00884 \\
(0.00946)\end{array}$ & $\begin{array}{c}\text { 0.0172* } \\
(0.00899)\end{array}$ & $\begin{array}{c}0.0420 * * * \\
(0.00863)\end{array}$ & $\begin{array}{c}0.0409 * * * \\
(0.00894)\end{array}$ \\
\hline NII Share (\%) X Loan-to-Asset Ratio (\%) & $\begin{array}{c}-0.000659 * * * \\
(0.000166)\end{array}$ & $\begin{array}{c}-0.000617^{* * *} \\
(0.000177)\end{array}$ & $\begin{array}{c}-0.000412^{* *} \\
(0.000181)\end{array}$ & $\begin{array}{c}-0.000495^{* * *} . \\
(0.000187)\end{array}$ & $\begin{array}{r}-0.000706 * * * \\
(0.000176)\end{array}$ & $\begin{array}{c}\cdot 0.000716 * * * \\
(0.000184)\end{array}$ \\
\hline Tier 1 Ratio (\%) & $\begin{array}{c}-0.0363 \\
(0.0221)\end{array}$ & $\begin{array}{c}-0.0677^{* * *} \\
(0.0188)\end{array}$ & $\begin{array}{c}-0.0324 * \\
(0.0171)\end{array}$ & $\begin{array}{c}-0.0544^{* * *} \\
(0.0195)\end{array}$ & $\begin{array}{c}-0.0562 * * * \\
(0.0194)\end{array}$ & $\begin{array}{c}-0.0836 * * * \\
(0.0242)\end{array}$ \\
\hline Problem Loans Ratio (\%) & $\begin{array}{c}-0.0267 * * * \\
(0.00863)\end{array}$ & $\begin{array}{l}-0.0183^{*} \\
(0.0101)\end{array}$ & $\begin{array}{c}-0.0467 * * * \\
(0.00989)\end{array}$ & $\begin{array}{c}-0.0355^{* * *} \\
(0.0108)\end{array}$ & $\begin{array}{c}-0.0261 * * * \\
(0.00843)\end{array}$ & $\begin{array}{l}-0.0187 * * \\
(0.00836)\end{array}$ \\
\hline Real GDP growth rate (\%) & $\begin{array}{l}-0.237 * * * \\
(0.0298)\end{array}$ & $\begin{array}{c}-0.260 * * * \\
(0.0295)\end{array}$ & $\begin{array}{c}-0.213^{* * *} \\
(0.0286)\end{array}$ & $\begin{array}{c}-0.241 * * * \\
(0.0285)\end{array}$ & $\begin{array}{c}-0.230 * * * \\
(0.0283)\end{array}$ & $\begin{array}{c}-0.244^{* * *} \\
(0.0287)\end{array}$ \\
\hline ST interest rate (\%) & $\begin{array}{c}0.0945^{* * *} \\
(0.0294)\end{array}$ & $\begin{array}{c}0.117 * * * \\
(0.0257)\end{array}$ & $\begin{array}{c}0.0121 \\
(0.0204)\end{array}$ & $\begin{array}{c}0.0316 \\
(0.0207)\end{array}$ & $\begin{array}{c}0.0491 * * * \\
(0.0180)\end{array}$ & $\begin{array}{c}\mathbf{0 . 0 5 4 5 * * *} \\
(0.0200)\end{array}$ \\
\hline Gov Structural Balance/Potential GDP & $\begin{array}{l}-0.138 * * * \\
(0.0201)\end{array}$ & $\begin{array}{c}-0.132 * * * \\
(0.0206)\end{array}$ & $\begin{array}{c}-0.171^{* * *} \\
(0.0209)\end{array}$ & $\begin{array}{c}-0.152^{* * *} \\
(0.0210)\end{array}$ & $\begin{array}{c}-0.133^{* * *} \\
(0.0188)\end{array}$ & $\begin{array}{c}-0.131 * * * \\
(0.0222)\end{array}$ \\
\hline Lerner Index (\%) & $\begin{array}{c}0.0156 * \\
(0.00807)\end{array}$ & $\begin{array}{c}0.0186 * * * \\
(0.00674)\end{array}$ & & & & \\
\hline Deposit-to-Liability Ratio (\%) & & & $\begin{array}{c}-0.0328 * * * \\
(0.00636)\end{array}$ & $\begin{array}{c}-0.0249 * * * \\
(0.00589)\end{array}$ & & \\
\hline Leverage Ratio & & & & & $\begin{array}{l}0.00945^{*} \\
(0.00537)\end{array}$ & $\begin{array}{l}\text { 0.0279* } \\
(0.0166)\end{array}$ \\
\hline Weekly Delta CoVaR $=\mathrm{L}$ & $\begin{array}{c}\mathbf{0 . 1 3 4 * * *} \\
(0.0216)\end{array}$ & $\begin{array}{l}0.140 * * * \\
(0.0228)\end{array}$ & $\begin{array}{c}\mathbf{0 . 1 2 7 * * *} \\
(0.0219)\end{array}$ & $\begin{array}{c}0.138 * * * \\
(0.0220)\end{array}$ & $\begin{array}{c}\mathbf{0 . 1 4 6 * * *} \\
(0.0210)\end{array}$ & $\begin{array}{c}0.154^{* * *} \\
(0.0336)\end{array}$ \\
\hline Observations & 3,864 & 3,830 & 3,916 & 3,883 & 3,919 & 3,886 \\
\hline Hansen $p$-Value & 0.318 & 0.370 & 0.291 & 0.318 & 0.336 & 0.109 \\
\hline
\end{tabular}

It is interesting to note that the Lerner index is positively associated with the contribution to systemic risk, but negatively associated with idiosyncratic risks ${ }^{38}$. One potential explanation

\footnotetext{
${ }^{38}$ The effect of Lerner index is not driven by bank size. In our sample, the correlation between the Lerner index and market power are weak (at 0.10). In general, there is mixed evidence between bank size and bank market power, both theoretically and empirically. Some studies predict a positive relation (e.g., consider a Cournot competition model). Others predict a negative one - as larger banks tend to operate on a larger (national or international) market whereas smaller ones locally (e.g., smaller banks focus on relationship banking, where
} 
is that while higher mark-up is beneficial for banks at the bank-specific level, it could increase risks at the system level due to the excessive market power of some banks. This is consistent with the findings for U.S. banks in Anginer, Demirgüç-Kunt, and Zhu (2014), which suggest that higher competition (lower mark-up) reduces systemic risks. ${ }^{39}$

These empirical findings suggest that the source and the sustainability of bank profitability could carry important financial stability implications. An over-reliance on leverage, wholesale funding sources, and market-based NII tends to be associated with higher idiosyncratic risk and contribution to systemic risks. Consequently, policy makers and financial stability authorities should pay more attention to the source of bank profitability in assessing the resilience of banks to systemic stress. This should also feed into the design and the calibration of macro-prudential stress tests. ${ }^{40}$ Furthermore, the differentiating impact of competition on idiosyncratic and systemic risks calls for policy makers to strike a balance between cost reductions (through bank consolidation) and a competitive and stable banking environment. One approach to facilitate a competitive banking environment is to allow for the entry of new firms instead of raising domestic and foreign entry barriers into the financial sector to unnecessarily high levels (Anginer, Demirgüç-Kunt, and Zhu 2014).

A number of further robustness checks were carried out, including using various lagspecifications as instruments in the dynamic panel regression, re-running the regressions using static panels with fixed effects against lagged independent variables, and including time dummies (year-fixed effects). The results are found to be robust (see Appendix IV for details).

\section{B. Determinants of Bank Profitability}

Having established the importance of bank profitability for financial stability, this subsection examines the determinants or factors that influence bank profitability. Bank

\footnotetext{
they exploit higher rents from asymmetric information and higher switching costs of borrowers). See Bikker, Spierdijk, and Finnie (2006).

39 The NPL ratio is found to be positively associated with idiosyncratic risk but negatively associated with systemic risk. One potential explanation here is that systemic risk is related to the degree of interconnectedness of one bank with the rest of the market (Diebold and Yilmaz 2014; Malik and Xu 2017), and therefore marketbased activities are more influential in banks' contribution to systemic risk, compared with retail-based activities that typically determine banks' problem loan ratios. After controlling for common cyclical conditions (GDP growth), the problem loan ratio tends to reflect bank-specific risk appetite and risk management practices, which may be different from that of other banks. As a result, the problem loan ratio could have a low or negative beta compared with general market movements and could be negatively associated with banks' contribution to systemic risks.

40 Typically, in a stress testing exercise, bank profitability matters through retained earnings and capital adequacy. However, more attention could be paid to the source and the sustainability in a systemic risk analysis of the financial system (for example, by including a detailed profitability analysis alongside the stress testing exercise).
} 
profitability is measured by five different variables: ROAA, ROAE, price-to-book ratio, riskadjusted ROAA, and risk-adjusted ROAE scaled by standard deviations of bank returns.

\begin{tabular}{|c|c|c|c|c|c|}
\hline \multicolumn{6}{|c|}{ Table 4. Empirical Results: Determinants of Profitability } \\
\hline & (1) & (2) & (3) & (4) & (5) \\
\hline VARIABLES & ROAA & ROAE & RAROAA & RAROAE & Price/Book \\
\hline \multirow[t]{2}{*}{ Problem Loans Ratio } & $-0.0199 * *$ & $-0.236 * *$ & $-0.0131 * *$ & $-0.0226 * * *$ & $-1.121 * * *$ \\
\hline & $(0.00904)$ & (0.0950) & $(0.00584)$ & $(0.00643)$ & $(0.297)$ \\
\hline \multirow[t]{2}{*}{ Cost-to-Income (\%) } & $-0.0290 * * *$ & $-0.326 * * *$ & $-0.0130 * * *$ & $-0.0161 * * *$ & $-0.440 * * *$ \\
\hline & $(0.00312)$ & $(0.0375)$ & $(0.00279)$ & $(0.00279)$ & $(0.127)$ \\
\hline \multirow[t]{2}{*}{ Cost of Funds (\%) } & $-0.139 * * *$ & 0.0378 & -0.0304 & 0.0354 & $-12.88 * * *$ \\
\hline & $(0.0414)$ & $(0.473)$ & $(0.0422)$ & $(0.0461)$ & $(3.748)$ \\
\hline \multirow[t]{2}{*}{ Real GDP growth rate } & $0.0591 * * *$ & $0.955 * * *$ & $0.0875^{* * *}$ & $0.0817^{* * *}$ & 0.646 \\
\hline & $(0.0124)$ & $(0.193)$ & (0.0129) & $(0.0138)$ & $(0.627)$ \\
\hline \multirow[t]{2}{*}{ ST interest rate } & $0.0724 * * *$ & 0.0737 & $-0.0691 * *$ & $-0.0952 * * *$ & 3.832 \\
\hline & $(0.0247)$ & $(0.309)$ & $(0.0291)$ & $(0.0313)$ & $(2.330)$ \\
\hline \multirow[t]{2}{*}{ Gov Structural Balance/Potential GDP } & $0.0130 *$ & $0.171 *$ & 0.0163 & $0.0307 * * *$ & 0.503 \\
\hline & $(0.00759)$ & $(0.0892)$ & $(0.0120)$ & $(0.0114)$ & (0.399) \\
\hline \multirow[t]{2}{*}{ Claim growth rate } & $4.91 \mathrm{e}-05^{* * *}$ & $0.000331 * * *$ & $1.46 \mathrm{e}-06$ & $5.53 e-06$ & $-3.53 e-05$ \\
\hline & $(4.18 \mathrm{e}-06)$ & $(4.68 \mathrm{e}-05)$ & $(1.79 \mathrm{e}-05)$ & $(1.34 \mathrm{e}-05)$ & $(0.000254)$ \\
\hline \multirow[t]{2}{*}{ Log(Assets) } & $-0.0959 * * *$ & $-0.802 * * *$ & $-0.0831 * * *$ & $-0.0563 * *$ & -0.278 \\
\hline & $(0.0232)$ & $(0.277)$ & $(0.0229)$ & $(0.0229)$ & $(0.924)$ \\
\hline \multirow[t]{2}{*}{$\mathrm{ROAA}=\mathrm{L}$} & $0.109 *$ & & & & \\
\hline & $(0.0600)$ & & & & \\
\hline \multirow[t]{2}{*}{$\operatorname{ROAE}(\%)=\mathrm{L}$} & & $0.224 * * *$ & & & \\
\hline & & $(0.0684)$ & & & \\
\hline \multirow[t]{2}{*}{ ROAA/SD from all sample periods $=\mathrm{L}$} & & & $0.749 * * *$ & & \\
\hline & & & $(0.0261)$ & & \\
\hline \multirow[t]{2}{*}{$\mathrm{ROAE} / \mathrm{SD}$ from all sample periods $=\mathrm{L}$} & & & & $0.744 * * *$ & \\
\hline & & & & $(0.0280)$ & \\
\hline \multirow[t]{2}{*}{ Price-to-Book Ratio = L } & & & & & $0.658 * * *$ \\
\hline & & & & & $(0.0251)$ \\
\hline Observations & 4,265 & 4,240 & 4,265 & 4,240 & 3,927 \\
\hline Hansen $p$-Value & 0.189 & 0.121 & 0.225 & 0.254 & 0.245 \\
\hline \multicolumn{6}{|c|}{$\begin{array}{l}\text { Robust standard errors in parentheses. }{ }^{* * *} p<0.01,{ }^{* *} p<0.05,{ }^{*} p<0.1 . \text { Risk-adjusted profitability measures (RAROAA } \\
\text { and RAROAE) are computed by taking the ratio of headline profitability measures (ROAA and ROAE) and their standard } \\
\text { deviation for the sample period from } 2004 \text { to } 2017 \text { for each bank. }\end{array}$} \\
\hline
\end{tabular}

See Appendix III for sources and definitions of the variables.

As predicted by the stylized theoretical model, the problem loan ratio and the cost-to-income ratio are negatively associated with bank profitability (Table 4), confirming hypothesis 4 . A higher problem loan ratio is typically matched by higher provisioning costs, and therefore negatively affecting bank profitability. For instance, a one standard deviation decrease in the problem loan ratio is associated with a 0.1 percentage point increase in the ROAA, which is more than ten percent of the median value of ROAA ( 0.83 percent $)$. As expected, a high cost- 
to-income ratio and high funding costs are associated with lower profitability, which follows directly from the accounting relationship of bank profits and losses. Consistent with the literature, a more favorable macroeconomic environment is associated with higher profitability (e.g., Kok, Móré, and Pancaro 2015; IMF 2017).

The results on profitability are also robust to different lag-specifications, the inclusion of year dummies, and the use of static panel regressions. In addition, using pre-tax income in the calculation of ROAA, ROAE, and risk-adjusted ROAA, ROAE does not affect the conclusion. The details are provided in Appendix IV.

\section{Policy Implications And Conclusions}

This paper investigates the relationship between bank profitability and financial stability, accounting for bank business models and different NII activities. It also examines the importance of the various determinants of banking risks and profitability. The paper first develops a stylized theoretical model that captures bank risks and retail-based and marketbased NII activities. It then estimates a panel regression model for 431 publicly traded banks from 2004 to 2017.

The stylized theoretical model establishes the analytical relationship between financial stability and bank profitability, and between financial stability and business models captured by NII activities. The model predicts that idiosyncratic risks, captured by the VaR of equity prices and the EDF, are negatively related to both ROAA and long-term expected profitability (i.e., charter value). Profits reduce risks by providing equity buffers, and by encouraging prudence and reduced risk-taking. In addition, idiosyncratic risk rises with the share of NII activities when the LTA ratio is below a certain threshold. Idiosyncratic risk also increases with the leverage ratio of banks. The theoretical model also predicts that profitability decreases as the problem loan ratio, operating costs, and funding costs increase.

The empirical results confirm the theoretical predictions on bank profitability and financial stability. First, profitability (ROAA) and the price-to-book ratio are negatively associated with both contribution to systemic risk $(\triangle \mathrm{CoVaR})$ and idiosyncratic risk measured by $\mathrm{VaR}$ and the EDF of banks. Second, a high NII share tends to be associated with higher idiosyncratic risk and contribution to systemic risk when the LTA ratio is low (i.e., when a bank's business model is less retail-oriented), as predicted by the theoretical model. Third, lower competition (high mark-up) is associated with lower idiosyncratic risk but higher contribution to systemic risk. Fourth, the empirical results suggest that high leverage and over-reliance on wholesale funding are associated with higher risks. Finally, asset quality, measured by the problem loans ratio, cost efficiency (cost-to-income ratio), and funding costs are important determinants of bank profitability (e.g., ROAA, ROAE, and risk-adjusted returns) and price-to-book ratio.

These findings raise several interesting issues for policy makers and financial stability authorities. First, the results highlight the need for a sharper distinction between different types of NII activities. In general, market-based NII activities are riskier than retail-based NII activities. This is an important consideration. In a low interest rate environment, banks tend 
to diversify into NII activities, but this causes a shift in a bank's risk profile. Second, it would be important to account for the impact of bank consolidation on competition and systemic risks. Low competition is associated with high contribution to systemic risk but low idiosyncratic risk. After the recent GFC experience, there was a rise in mergers and acquisitions between banks. While beneficial for banks at the firm level, lower competition as measured by a higher Lerner index appears to be negatively associated with banks' contribution to systemic risk. From a financial stability policy viewpoint, the right balance between cost efficiency and a competitive and stable banking environment is an important consideration. Third, these results highlight the need to evaluate the sustainability of bank profitability. An over-reliance on leverage and wholesale funding are associated with higher idiosyncratic and contribution to systemic risks and thereby lower financial stability. Policy makers and financial stability authorities should pay more attention to the source and the sustainability of bank profitability in the design and the calibration of macro-prudential stress tests and systemic risk analysis. These findings also underscore the importance of the effective and timely implementation of the Basel III framework, the need for well calibrated macro-prudential tools, and to ensure that banks' reliance on wholesale funding and leverage remains prudentially manageable. 


\section{APPENDIX I: A SELECTED LITERATURE REVIEW}

This review surveys recent research on bank profitability and financial stability from theoretical, empirical, and policy perspectives. We focus on three areas that are closest to our analysis on the determinants of risks and bank profitability. The key determinants can be grouped into three main types: 1) bank business models, including the role of NII and bank characteristics; 2) cyclical conditions and structural factors, including concentration and competition; and 3) policy factors in influencing bank profitability and financial stability.

The literature on bank business models examines bank performance and risks across different business models. An important aspect of diversification in business model emphasized in the literature is the implication of NII activities, which has shown mixed evidence. Most empirical studies on U.S. banks conclude that increased reliance on NII has little to no impact on lifting bank profits and offsetting the debilitating effect of return volatilities (e.g., DeYoung and Roland 2001; Stiroh 2006; Stiroh and Rumble 2006; Calmes and Liu 2009; and Kok, Móré, and Pancaro 2015). International studies, particularly those of European banks, paint a brighter picture and suggest a "diversification premium," implying that banks with more diversified revenue streams are more profitable, but the benefit of NII is still debatable (e.g., Baele, De Jonghe, and Vander Vennet 2007; Elsas, Hackethal, and Holzhauser 2010; Sanya and Wolfe 2011; Calmes and Theoret 2010; Lepetit et al. 2008; and Kohler 2015).

Some recent papers propose a more nuanced and non-linear relationship between income diversification and risks. NII activities are found to be beneficial when the NII share is low (Boot and Ratnovski 2016; Demirgüç-Kunt and Huizinga 2010), or when banks are small (De Jonghe, Diepstraten, and Schepens 2015; Abedifar, Molyneux, and Tarazi 2018). Furthermore, based on supervisory data in Germany, Kohler (2014) found that diversification into NII activities were more beneficial for retail-oriented banks such as savings and cooperative banks. Using U.S. banking “call reports", DeYoung and Torna (2013) concluded that the probability of distressed bank failure declined with pure fee-based NII activities but increased with asset-based NII like investment banking and securitization. Besides bank idiosyncratic return and risks, NIIs are also shown to increase systemic risks of the banking sector (De Jonghe, Diepstraten, and Schepens 2015; Brunnermeier, Dong, and Palia 2012; and Engle et al. 2014).

A number of studies found that efficiency, typically measured by the cost-to-income ratio, is an important driver of bank profitability (Molyneux and Thornton 1992; Kok, Móré, and Pancaro 2015; IMF 2017). The impact of bank capital on profitability is found to be ambiguous. On the one hand, banks with higher capital ratios tend to face lower funding costs owing to lower prospective bankruptcy costs (Berger 1995). On the other hand, higher capitalization can be associated with lower risk-taking, which in turn leads to lower (expected) returns (Goddard, Molyneux, and Wilson 2004). Recent empirical evidence, especially after 2009, suggests a negative association between credit risk and profitability (Kok, Móré, and Pancaro 2015; IMF 2017).

Many studies incorporate macroeconomic variables into the analysis to examine cyclical patterns in bank performance and behavior. Bank profitability tends to be pro-cyclical, driven 
by cyclical patterns in lending and other financial intermediation activities, and by loan loss provisions (Albertazzi and Gambacorta 2009; Kok, Móré, and Pancaro 2015; IMF 2017). Turning to structural factors affecting bank profitability, competition and market concentration are the most frequently examined variable in this respect. Theoretically, competition is shown to dampen bank profitability (Klein 1971; Monti1972; Freixas and Rochet 2008; Ho and Saunders 1981) ${ }^{41}$, but competition affect risks non-monotonically. ${ }^{42}$ Empirically, the estimation of competition and market power is challenging, and the impact of banking market structure is ambiguous (Berger, Klapper, and Turk-Ariss 2009; Vives 2010; Beck, Demirgüç-Kunt, and Levine 2006).

On monetary policy, there is evidence that bank margin increases with policy rates. Drechsler, Savov, and Schnabl (2017) show that banks increase their spreads over deposits when the federal funds rate rises. Genay and Podjasek (2014) find that U.S. banks are adversely affected by interest rates that are low for an extended period of time due to narrower net interest margins (NIM) in the U.S. Claessens, Coleman, and Donnelly (2016) conclude that low interest rates negatively affect the NIMs of banks in the euro area, Canada, Japan, the U.K. and the U.S. Furthermore, Borio, Gambacorta, and Hofmann (2017) identify a non-linear relationship between interest rates and bank profits in a cross-country setting, both theoretically and empirically. On fiscal policy, there is a large literature on the real effects of financial sector interventions during crises (e.g., Dell'Ariccia, Detragiache, and Rajan 2008; Laeven and Valencia, 2013). While there is mixed evidence on the effectiveness of financial sector interventions, Laeven and Valencia (2013) found evidence for discretionary fiscal policy and bank capitalization in supporting the growth of financiallydependent firms.

\footnotetext{
41 There are two classes of models: bank/firm-theoretical models and dealership models. For the former, see Klein (1971), Monti (1972), and Freixas and Rochet (2008). For the latter, see Ho and Saunders (1981).

42 On the one hand, competition destroys bank franchise value and thus incentive for prudence (Keeley 1990; Besanko and Thakor 1993; Matutes and Vives 2000; Repullo 2004). On the other hand, lower interest margin resulted from competition can reduce credit rationing (Boyd and De Nicolo 2005; Stiglitz and Weiss 1981). Martinez-Miera and Repullo (2010) reconcile these two arguments in a unified model, presenting a U-shaped relationship between competition and bank risks.
} 


\section{Appendix II: Proofs of Propositions ANd Lemmas}

Proposition 1: Bank idiosyncratic risks measured by EDF and VaR are decreasing in the (expected) $R O A \mu_{\pi}^{*}$ :

$$
\frac{\partial E D F}{\partial \mu_{\pi}^{*}}<0 \quad \frac{\partial V a R}{\partial \mu_{\pi}^{*}}<0
$$

\section{Proof:}

Start from EDF. At optimal, EDF $\equiv 1-q^{*}=1-\Phi\left(\frac{\mu_{\pi}^{*}+e}{\sigma_{\pi}^{*}}\right)$. So $\frac{\partial q^{*}}{\partial \mu_{\pi}^{*}}=\frac{\phi\left(\frac{\mu_{\pi}^{*}+e}{\sigma_{\pi}^{*}}\right)}{\sigma_{\pi}^{*}}>0$, and thus

$$
\frac{\partial E D F}{\partial \mu_{\pi}^{*}}=-\frac{\partial q^{*}}{\partial \mu_{\pi}^{*}}<0
$$

$V a R$ is defined by an implicit function $F\left(V a R, \mu_{\pi}, \sigma_{\pi}\right)$, where

$$
F=\Phi\left(\frac{-V a R-\mu_{\pi}^{*}-e}{\sigma_{\pi}^{*}}\right)-0.05=0
$$

To ease notation, denote $\frac{-V a R-\mu_{\pi}^{*}-e}{\sigma_{\pi}^{*}}=C_{1}$

$$
\begin{gathered}
\frac{\partial F}{\partial V a R}=-\frac{1}{\sigma_{\pi}^{*}} \phi\left(C_{1}\right)<0 \\
\frac{\partial F}{\partial \mu_{\pi}^{*}}=-\frac{1}{\sigma_{\pi}^{*}} \phi\left(C_{1}\right)<0
\end{gathered}
$$

By implicit function theorem,

$$
\frac{\partial V a R}{\partial \mu_{\pi}^{*}}=-\frac{\frac{\partial F}{\partial \mu_{\pi}^{*}}}{\frac{\partial F}{\partial V a R}}<0
$$

Q.E.D.

Lemma A1: $q^{*}$ is decreasing in the standard deviation of $R O A\left(\sigma_{\pi}^{*}\right)$, and VaR is increasing in the standard deviation of $\operatorname{ROA}\left(\sigma_{\pi}^{*}\right)$, if $\mu_{\pi}^{*}+e>\epsilon$.

$$
\frac{\partial q^{*}}{\partial \sigma_{\pi}^{*}}<0 \quad \frac{\partial V a R}{\partial \sigma_{\pi}^{*}}>0 \text { if } \mu_{\pi}^{*}+e>\epsilon
$$

Proof:

Also

$$
\frac{\partial q^{*}}{\partial \sigma_{\pi}^{*}}=-\phi\left(\frac{\mu_{\pi}^{*}+e}{\sigma_{\pi}^{*}}\right) \frac{\mu_{\pi}^{*}+e}{\sigma_{\pi}^{* 2}}<0
$$


By the implicit function theorem,

$$
\frac{\partial F}{\partial \sigma_{\pi}^{*}}=\frac{V a R+\mu_{\pi}^{*}+e}{\sigma_{\pi}^{* 2}} \phi\left(C_{1}\right)>0
$$

Q.E.D.

$$
\frac{\partial V a R}{\partial \sigma_{\pi}^{*}}=-\frac{\frac{\partial F}{\partial \sigma_{\pi}^{*}}}{\frac{\partial F}{\partial V a R}}>0
$$

Lemma A2: The (expected) $R O A \mu_{\pi}^{*}$ is increasing in the LTA ratio l, under certain regularity conditions.

$$
\frac{\partial \mu_{\pi}^{*}}{\partial l}>0 \text { if } l<\frac{1}{1+k} \text { and } x<1+\frac{\left(r_{m}-c_{m}\right)\left(\frac{1-\alpha}{\alpha} k-1\right)+\frac{1-\alpha}{\alpha} k c_{r}}{r_{L}}
$$

\section{Proof:}

$\mu_{\pi}^{*}=\left\{\begin{array}{cc}(1-x) r_{L} l+r_{r}(1-l)^{\alpha} l^{1-\alpha}-c_{r}(1-l)-r_{D}(1-e)-c_{f} & \text { if } l \geq \frac{1}{1+k} \\ (1-x) r_{L} l+\left(r_{m}-c_{m}\right)(1-l-k l)+r_{r} k^{\alpha} l-c_{r} k l-r_{D}(1-e)-c_{f} & \text { if } l<\frac{1}{1+k}\end{array}\right.$

If $<\frac{1}{1+k}, \frac{\partial \mu_{\pi}^{*}}{\partial l}=(1-x) r_{L}-\left(r_{m}-c_{m}\right)(1+k)+r_{r} k^{\alpha}-c_{r} k$ where $k=\left(\frac{\alpha r_{r}}{c_{r}+r_{m}-c_{m}}\right)^{\frac{1}{1-\alpha}}$

Note that $r_{r} k^{\alpha}-c_{r} k=k\left(r_{r} k^{\alpha-1}-c_{r}\right)=\frac{k}{\alpha}\left[c_{r}(1-\alpha)+r_{m}-c_{m}\right]$. Therefore, $\frac{\partial \mu_{\pi}^{*}}{\partial l}>0$ if and only if $(1-x) r_{L}-\left(r_{m}-c_{m}\right)(1+k)+\frac{k}{\alpha}\left[c_{r}(1-\alpha)+r_{m}-c_{m}\right]=(1-x) r_{L}+$ $\left(r_{m}-c_{m}\right)\left(\frac{1-\alpha}{\alpha} k-1\right)+\frac{1-\alpha}{\alpha} k c_{r}>0$. Equivalently, when $x<1+\frac{\left(r_{m}-c_{m}\right)\left(\frac{1-\alpha}{\alpha} k-1\right)+\frac{1-\alpha}{\alpha} k c_{r}}{r_{L}}$ A sufficient condition will be $k>\frac{\alpha}{1-\alpha}$

Q.E.D.

Lemma A3: The standard deviation of ROA $\left(\sigma_{\pi}^{*}\right)$ is decreasing in the LTA ratio l, under certain regularity conditions.

$$
\frac{\partial \sigma_{\pi}^{*}}{\partial l}<0 \text { if } l<\underline{l}=\frac{(1+k) \sigma_{m}^{2}}{(1-x)^{2} \sigma_{L}^{2}+(1+k)^{2} \sigma_{m}^{2}+k^{2 \alpha} \sigma_{r}^{2}}<\frac{1}{1+k}
$$

\section{Proof:}




$$
\sigma_{\pi}^{2 *}=\left\{\begin{array}{cc}
(1-x)^{2} l^{2} \sigma_{L}^{2}+(1-l)^{2 \alpha} l^{2-2 \alpha} \sigma_{r}^{2} & \text { if } l \geq \frac{1}{1+k} \\
(1-x)^{2} l^{2} \sigma_{L}^{2}+(1-l-k l)^{2} \sigma_{m}^{2}+k^{2 \alpha} l^{2} \sigma_{r}^{2} & \text { if } l<\frac{1}{1+k}
\end{array}\right.
$$

If $<\frac{1}{1+k}, \frac{\partial \sigma_{\pi}^{2 *}}{\partial l}=\left[2(1-x)^{2} \sigma_{L}^{2}+2(1+k)^{2} \sigma_{m}^{2}+2 k^{2 \alpha} \sigma_{r}^{2}\right] l-2(1+k) \sigma_{m}^{2}<0$ if and only

if $l<\underline{l}=\frac{(1+k) \sigma_{m}^{2}}{(1-x)^{2} \sigma_{L}^{2}+(1+k)^{2} \sigma_{m}^{2}+k^{2 \alpha} \sigma_{r}^{2}}=\frac{1}{\frac{(1-x)^{2} \sigma_{L}^{2}}{(1+k) \sigma_{m}^{2}}+(1+k)+\frac{k^{2 \alpha} \sigma_{r}^{2}}{(1+k) \sigma_{m}^{2}}}<\frac{1}{1+k}$

Therefore,

$$
\frac{\partial \sigma_{\pi}^{*}}{\partial l}=\frac{1}{2 \sigma_{\pi}^{*}} \frac{\partial \sigma_{\pi}^{2 *}}{\partial l}<0
$$

Q.E.D.

Proposition 2: When LTA ratio (l) is below a certain threshold (l), higher NII share(s) will lead to higher VaR and EDF:

$$
\frac{\partial E D F}{\partial s}>0 \quad \frac{\partial V a R}{\partial s}>0 \text { if } l \leq \underline{l}=\frac{(1+k) \sigma_{m}^{2}}{(1-x)^{2} \sigma_{L}^{2}+(1+k)^{2} \sigma_{m}^{2}+k^{2 \alpha} \sigma_{r}^{2}}<\frac{1}{1+k}
$$

under a regularity condition. ${ }^{43}$

\section{Proof:}

Base on the proof of proposition 1, Lemma A1 to A3, we have

$$
\begin{gathered}
\frac{\partial E D F}{\partial s}=\frac{\partial E D F}{\partial n}=-\frac{\partial E D F}{\partial l}=\frac{\partial q^{*}}{\partial l}=\frac{\partial q^{*}}{\partial \mu_{\pi}^{*}} \frac{\partial \mu_{\pi}^{*}}{\partial l}+\frac{\partial q^{*}}{\partial \sigma_{\pi}^{*}} \frac{\partial \sigma_{\pi}^{*}}{\partial l}>0 \\
\frac{\partial E D F}{\partial n}=-\frac{\partial V a R}{\partial l}=-\frac{\partial V a R}{\partial \mu_{\pi}^{*}} \frac{\partial \mu_{\pi}^{*}}{\partial l}-\frac{\partial V a R}{\partial \sigma_{\pi}^{*}} \frac{\partial \sigma_{\pi}^{*}}{\partial l}>0
\end{gathered}
$$

when $x<1+\frac{\left(r_{m}-c_{m}\right)\left(\frac{1-\alpha}{\alpha} k-1\right)+\frac{1-\alpha}{\alpha} k c_{r}}{r_{L}}$.

Also,

$$
\begin{aligned}
& \frac{\partial E D F}{\partial s}=\frac{\partial E D F}{\partial n} \frac{\partial s}{\partial n}>0 \\
& \frac{\partial V a R}{\partial s}=\frac{\partial V a R}{\partial n} \frac{\partial s}{\partial n}>0
\end{aligned}
$$

Q.E.D.

${ }^{43}$ The regularity condition is that the problem loan ratio $x<1+\frac{\left(r_{m}-c_{m}\right)\left(\frac{1-\alpha}{\alpha} k-1\right)+\frac{1-\alpha}{\alpha} k c_{r}}{r_{L}}$. This parameter assumption is reasonable, as the average value of $x$ observed empirically in our sample is less than $5 \%$. 
Corollary 1: $E D F$ and VaR are decreasing $\frac{E}{A}=e$ (increasing in leverage $\frac{1}{e}$ )

$$
\frac{\partial E D F}{\partial e}<0 \quad \frac{\partial V a R}{\partial e}<0
$$

\section{Proof:}

Similar to the proof in proposition 1,

$$
\begin{gathered}
\frac{\partial E D F}{\partial e}=-\frac{\partial q^{*}}{\partial e}=-\frac{\phi\left(\frac{\mu_{\pi}^{*}+e}{\sigma_{\pi}^{*}}\right)}{\sigma_{\pi}^{*}}<0 \\
\frac{\partial F}{\partial e}=-\frac{1}{\sigma_{\pi}^{*}} \phi\left(C_{1}\right)<0
\end{gathered}
$$

By implicit function theorem,

$$
\frac{\partial V a R}{\partial e}=-\frac{\frac{\partial F}{\partial e}}{\frac{\partial F}{\partial V a R}}<0
$$

Q.E.D.

Proposition 3: Expected profits are decreasing in problem loan ratio $x$, cost $c_{f}$, and funding $\operatorname{cost} r_{D}$ :

$$
\frac{\partial \mu_{\pi}^{*}}{\partial x}<0 \quad \frac{\partial \mu_{\pi}^{*}}{\partial c_{f}}<0 \quad \frac{\partial \mu_{\pi}^{*}}{\partial r_{D}}<0
$$

\section{Proof:}

Note that:

$$
\mu_{\pi}^{*}=\left\{\begin{array}{cc}
(1-x) r_{L} l+r_{r}(1-l)^{\alpha} l^{1-\alpha}-c_{r}(1-l)-r_{D}(1-e)-c_{f} & \text { if } l \geq \frac{1}{1+k} \\
(1-x) r_{L} l+\left(r_{m}-c_{m}\right)(1-l-k l)+r_{r} k^{\alpha} l-c_{r} k l-r_{D}(1-e)-c_{f} & \text { if } l<\frac{1}{1+k}
\end{array}\right.
$$

One can immediately derive that

$$
\frac{\partial \mu_{\pi}^{*}}{\partial x}=-r_{L} l<0 \quad \frac{\partial \mu_{\pi}^{*}}{\partial c_{f}}=-1<0 \quad \frac{\partial \mu_{\pi}^{*}}{\partial r_{D}}=e-1<0
$$

Q.E.D.

Proposition 4: Bank idiosyncratic risks measured by EDF' and VaR' are decreasing in the price-to-book ratio $v$ : 


$$
\frac{\partial E D F^{\prime}}{\partial v}<0, \quad \frac{\partial V a R^{\prime}}{\partial v}<0
$$

\section{Proof:}

Start from EDF. At optimal, $E D F^{\prime} \equiv 1-q^{*}=1-p^{*}\left[\Phi\left(\frac{\mu_{\pi}^{*}+e}{\sigma_{\pi}^{*}}\right)-\Phi\left(\frac{\mu_{\pi}^{*}+e-\epsilon}{\sigma_{\pi}^{*}}\right)\right]-$ $\Phi\left(\frac{\mu_{\pi}^{*}+e-\epsilon}{\sigma_{\pi}^{*}}\right)$. To ease notation, denote $B=\Phi\left(\frac{\mu_{\pi}^{*}+e}{\sigma_{\pi}^{*}}\right)-\Phi\left(\frac{\mu_{\pi}^{*}+e-\epsilon}{\sigma_{\pi}^{*}}\right)>0$, so

$$
\begin{gathered}
p^{*}=\frac{\epsilon+B e v}{b} \\
q^{*}=p^{*} B+\Phi\left(\frac{\mu_{\pi}^{*}+e-\epsilon}{\sigma_{\pi}^{*}}\right)
\end{gathered}
$$

Thus,

$$
\frac{\partial E D F^{\prime}}{\partial v}=-\frac{\partial q^{*}}{\partial v}=-B \frac{\partial p^{*}}{\partial v}=-\frac{e B^{2}}{b}<0
$$

$V a R$ is defined by an implicit function $F\left(V a R^{\prime}, \mu_{\pi}, \sigma_{\pi}, v\right)$, where

$$
F=\Phi\left(\frac{-V a R^{\prime}-\mu_{\pi}^{*}-e}{\sigma_{\pi}^{*}}\right) p^{*}+\Phi\left(\frac{-V a R^{\prime}-\mu_{\pi}^{*}-e+\epsilon}{\sigma_{\pi}^{*}}\right)\left(1-p^{*}\right)-0.05=0
$$

To ease notation, denote $\frac{-V a R^{\prime}-\mu_{\pi}^{*}-e}{\sigma_{\pi}^{*}}=C_{1}$ and $\frac{-V a R^{\prime}-\mu_{\pi}^{*}-e+\epsilon}{\sigma_{\pi}^{*}}=C_{2}>C_{1}$

$$
\begin{gathered}
\frac{\partial F}{\partial V a R^{\prime}}=-\frac{p^{*}}{\sigma_{\pi}^{*}} \phi\left(C_{1}\right)-\frac{1-p^{*}}{\sigma_{\pi}^{*}} \phi\left(C_{2}\right)<0 \\
\frac{\partial F}{\partial v}=-\frac{\partial p^{*}}{\partial v}\left[\Phi\left(C_{2}\right)-\Phi\left(C_{1}\right)\right]<0
\end{gathered}
$$

By implicit function theorem,

$$
\frac{\partial V a R^{\prime}}{\partial v}=-\frac{\frac{\partial F}{\partial v}}{\frac{\partial F}{\partial V a R^{\prime}}}<0
$$

Proposition 5: $E D F^{\prime}$ and $V a R$ ' are decreasing $\frac{E}{A}=e$ (increasing in leverage $\left.\frac{1}{e}\right)$ :

Q.E.D. 


$$
\frac{\partial E D F^{\prime}}{\partial e}<0 \quad \frac{\partial V a R^{\prime}}{\partial e}<0
$$

\section{Proof:}

Based on the proof of proposition $1, \frac{\partial B}{\partial e}=\frac{\left[\phi\left(\frac{\mu_{\pi}^{*}+e}{\sigma_{\pi}^{*}}\right)-\phi\left(\frac{\mu_{\pi}^{*}+e-\epsilon}{\sigma_{\pi}^{*}}\right)\right]}{\sigma_{\pi}^{*}}>0, \frac{\partial p^{*}}{\partial e}=\frac{e v}{b} \frac{\partial B}{\partial e}+\frac{B v}{b}>0$ and $\frac{\partial q^{*}}{\partial e}=p^{*} \frac{\partial B}{\partial e}+\frac{\partial p^{*}}{\partial e} B+\frac{\phi\left(\frac{\mu_{\pi}^{*}+e-\epsilon}{\sigma_{*}^{*}}\right)}{\sigma_{\pi}^{*}}>0$. Thus,

$$
\begin{gathered}
\frac{\partial E D F^{\prime}}{\partial e}=-\frac{\partial q^{*}}{\partial e}<0 \\
\frac{\partial F}{\partial e}=-\frac{p^{*}}{\sigma_{\pi}^{*}} \phi\left(C_{1}\right)-\frac{1-p^{*}}{\sigma_{\pi}^{*}} \phi\left(C_{2}\right)-\frac{\partial p^{*}}{\partial e}\left[\Phi\left(C_{2}\right)-\Phi\left(C_{1}\right)\right]<0
\end{gathered}
$$

By implicit function theorem,

$$
\frac{\partial V a R^{\prime}}{\partial e}=-\frac{\frac{\partial F}{\partial e}}{\frac{\partial F}{\partial V a R^{\prime}}}<0
$$

Q.E.D. 


\section{APPENDIX III: DATA SOURCES AND DEFINITIONS}

Appendix Table 1: Bank-Specific Variables

\begin{tabular}{|c|c|}
\hline Data series & Definition \\
\hline ROAA (\%) & Return on average assets; net income as a percent of average assets \\
\hline ROAE (\%) & Return on average equity; net income as a percent of average equity \\
\hline Price/Book (\%) & $\begin{array}{l}\text { Price as a percent of book value per share. Book value is calculated using } \\
\text { common equity values and shares outstanding at the end of a financial period }\end{array}$ \\
\hline Noninterest Income & Total operating income (revenues) excluding net interest income \\
\hline Operating Income & Total operating income from banking, insurance, and asset management \\
\hline $\begin{array}{l}\text { Total Gross } \\
\text { Loans }^{44}\end{array}$ & $\begin{array}{l}\text { Loans and finance leases held for investment or held for sale; net of } \\
\text { unearned discount and gross of loss reserves. }\end{array}$ \\
\hline Total Deposits & $\begin{array}{l}\text { Total deposits from customers. For U.S. banks, this is the total deposits from } \\
\text { customers and banks. }\end{array}$ \\
\hline Total Assets & $\begin{array}{l}\text { All assets owned by the company as of the date indicated, as carried on the } \\
\text { balance sheet and defined under the indicated accounting principles }\end{array}$ \\
\hline Total Liabilities & $\begin{array}{l}\text { Total liabilities as carried on the balance sheet and defined by the indicated } \\
\text { accounting principles. }\end{array}$ \\
\hline Total Equity & $\begin{array}{l}\text { Equity as defined under the indicated accounting principles. Includes par } \\
\text { value, paid in capital, retained earnings, and other adjustments to equity. } \\
\text { Minority interest may be included, per relevant accounting standards. }\end{array}$ \\
\hline Tier 1 Ratio (\%) & $\begin{array}{l}\text { Tier } 1 \text { capital ratio as defined by the latest regulatory and supervisory } \\
\text { guidelines. }\end{array}$ \\
\hline Problem Loans & $\begin{array}{l}\text { The problem loan value that the company most commonly presents. If the } \\
\text { company commonly reports multiple values, SNL selects based on the } \\
\text { following priority (at SNL's discretion): Nonperforming Loans, Gross } \\
\text { Impaired Loans, Net Impaired Loans, and Other Problem Loans. }\end{array}$ \\
\hline $\begin{array}{l}\text { Cost-to-Income } \\
(\%)\end{array}$ & Operating expense as a percent of operating income. \\
\hline Cost of Funds $(\%)$ & $\begin{array}{l}\text { Interest incurred on liabilities as a percent of average noninterest-bearing } \\
\text { deposits and interest-bearing liabilities }\end{array}$ \\
\hline $\begin{array}{l}\text { Compensation and } \\
\text { Benefits }\end{array}$ & $\begin{array}{l}\text { Salaries, wages, bonuses, commissions, changes in reserve for future stock } \\
\text { option expense, and other employee benefit costs. }\end{array}$ \\
\hline Interest Expense & $\begin{array}{l}\text { Interest on debt and other borrowings (on an incurred basis). Includes the } \\
\text { amortization of discount (or premiums) and interest on capital leases. }\end{array}$ \\
\hline Other Expense & Expense not otherwise classified. \\
\hline
\end{tabular}

Source: S\&P Global Market Intelligence's SNL database.

\footnotetext{
44 This definition of gross loans includes loans held for securitization, which, however, constitutes a small portion of total loans. The majority of gross loans are retail and corporate loans, and thus the loan-to-asset ratio is a good proxy for the traditional lending business of banks.
} 
Appendix Table 2: Financial Variables

\begin{tabular}{|c|c|c|}
\hline Data series & Source & Definition \\
\hline Equity prices & Bloomberg & Daily equity price, closing price \\
\hline $\begin{array}{l}\text { Expected Default Frequency } \\
\text { (EDF) (1 year) }\end{array}$ & Moody’s & $\begin{array}{l}\text { Forward-looking measure of actual probability of } \\
\text { default of a bank over one year. According to the } \\
\text { Moody's EDF model, a bank defaults when the } \\
\text { market value of its assets falls below its } \\
\text { liabilities payable }\end{array}$ \\
\hline 3-month T-bill rate & Bloomberg & Daily 3-month T-bill rate \\
\hline $\begin{array}{l}\text { 3-month German } \\
\text { government bond yield }\end{array}$ & Bloomberg & Daily 3-month German government bond yield \\
\hline 10-year T-bill rate & Bloomberg & Daily 10-year T-bill rate \\
\hline $\begin{array}{l}10 \text {-year German government } \\
\text { bond yield }\end{array}$ & Bloomberg & Daily 10-year German government bond yield \\
\hline 3-month LIBOR rate & Bloomberg & Daily 3-month LIBOR rate \\
\hline 3-month EURIBOR rate & Bloomberg & Daily 3-month EURIBOR rate \\
\hline $\begin{array}{l}\text { Credit spread of Moody's } \\
\text { Baa-rated bonds }\end{array}$ & Bloomberg & Daily credit spread of Moody's Baa-rated bonds \\
\hline Euro Stoxx Banks Index & Bloomberg & Daily equity index price, closing price \\
\hline Euro Stoxx 50 Index & Bloomberg & Daily equity index price, closing price \\
\hline $\begin{array}{l}\text { MSCI Europe Real Estate } \\
\text { Index }\end{array}$ & Bloomberg & Daily equity index price, closing price \\
\hline S\&P 500 Financials Index & Bloomberg & Daily equity index price, closing price \\
\hline S\&P 500 index returns & Bloomberg & Daily equity index price, closing price \\
\hline $\begin{array}{l}\text { Dow Jones U.S. Real Estate } \\
\text { Index }\end{array}$ & Bloomberg & Daily equity index price, closing price \\
\hline MSCI World Index & Bloomberg & Daily equity index price, closing price \\
\hline $\begin{array}{l}\text { MSCI World Financials } \\
\text { Index }\end{array}$ & Bloomberg & Daily equity index price, closing price \\
\hline $\begin{array}{l}\text { MSCI World Real Estate } \\
\text { Index }\end{array}$ & Bloomberg & Daily equity index price, closing price \\
\hline VIX Index & Bloomberg & Daily equity index price, closing price \\
\hline
\end{tabular}


Appendix Table 3: Macroeconomic Variables

\begin{tabular}{|l|l|l|}
\hline Data series & Source & Definition \\
\hline GDP growth & IMF WEO & $\begin{array}{l}\text { Growth of Gross Domestic Product, constant } \\
\text { prices }\end{array}$ \\
\hline Interest rate (3 month) & OECD & $\begin{array}{l}\text { Short term (3 months) interest rate, money } \\
\text { market }\end{array}$ \\
\hline $\begin{array}{l}\text { Government bond yield } \\
(10 \text { year) }\end{array}$ & $\begin{array}{l}\text { Haver } \\
\text { Analytics }\end{array}$ & 10-Year Government Bond Yield (AVG, \%) \\
\hline General government balance & IMF WEO & General government structural balance \\
\hline Central bank claims & $\begin{array}{l}\text { IMF MFS } \\
\text { statistics, Haver } \\
\text { Analytics }\end{array}$ & $\begin{array}{l}\text { Central Bank Survey, Claims on Other Financial } \\
\text { Corporations and Other Depository Corporations }\end{array}$ \\
\hline
\end{tabular}

\begin{tabular}{|c|c|c|c|c|c|c|}
\hline \multicolumn{7}{|c|}{ Appendix Table 4: Summary Statistics } \\
\hline & (1) & (2) & (3) & (4) & (5) & (6) \\
\hline VARIABLES & $\mathrm{N}$ & mean & p50 & sd & $\min$ & $\max$ \\
\hline Cost of Funds (\%) & 4,846 & 1.473 & 1.146 & 1.113 & 0.0476 & 7.374 \\
\hline Cost-to-Income (\%) & 5,304 & 65.40 & 63.98 & 17.88 & 25.27 & 347.1 \\
\hline Price-to-Book Ratio (\%) & 4,838 & 139.1 & 128.1 & 68.67 & 12.51 & 515.4 \\
\hline ROAA (\%) & 5,268 & 0.714 & 0.811 & 0.861 & -6.022 & 4.067 \\
\hline ROAE (\%) & 5,241 & 7.235 & 8.372 & 11.10 & -114.7 & 42.03 \\
\hline Tier 1 Ratio (\%) & 5,099 & 13.40 & 12.60 & 4.431 & 4.901 & 50.77 \\
\hline Problem Loans Ratio (\%) & 5,134 & 2.797 & 1.375 & 4.603 & 0 & 40.39 \\
\hline Loan-to-Asset Ratio (\%) & 5,306 & 65.72 & 68.59 & 15.08 & 10.01 & 92.24 \\
\hline Log(Assets) & 5,406 & 15.83 & 15.24 & 2.282 & 12.32 & 21.62 \\
\hline Non-Interest Income Share (\%) & 5,216 & 28.66 & 25.18 & 18.77 & 0.392 & 257.6 \\
\hline NII Share (\%) X Loan-to-Asset Ratio (\%) & 5,192 & 1,742 & 1,617 & 1,015 & 28.77 & 14,065 \\
\hline Deposit-to-Liability Ratio (\%) & 5,377 & 77.17 & 83.84 & 19.82 & 0 & 99.36 \\
\hline Leverage Ratio & 5,401 & 12.09 & 10.64 & 6.099 & 1.831 & 69.01 \\
\hline Lerner Index (\%) & 5,115 & 26.59 & 27.41 & 11.93 & -58.00 & 56.56 \\
\hline $\mathrm{ROAA} / \mathrm{sd}(\mathrm{ROAA})(\%)$ & 5,267 & 2.681 & 2.080 & 2.799 & -3.063 & 15.47 \\
\hline ROAA/sd(ROAE) (\%) & 5,239 & 2.461 & 1.876 & 2.657 & -3.144 & 15.16 \\
\hline Gov Structural Balance/Potential GDP (\%) & 5,992 & -4.463 & -4.258 & 2.645 & -19.39 & 4.360 \\
\hline ST Interest Rate (\%) & 5,966 & 1.554 & 0.644 & 1.792 & -0.784 & 15.82 \\
\hline Real GDP Growth Rate (\%) & 5,992 & 1.825 & 2.224 & 2.134 & -9.132 & 25.49 \\
\hline Claim Growth Rate (\%) & 5,780 & 90.46 & -14.16 & 381.5 & -94.40 & 6,332 \\
\hline Delta CoVaR (95\%) of Weekly Loss (\%) & 4,710 & 1.621 & 1.272 & 1.918 & -4.257 & 10.50 \\
\hline VaR (95\%) of Daily Loss (\%) & 4,722 & 3.118 & 2.569 & 1.901 & 0 & 12.71 \\
\hline Expected Default Frequency (\%) & 3,669 & 0.762 & 0.390 & 1.722 & 0.0198 & 25.15 \\
\hline $\operatorname{logit}(E D F)$ & 3,669 & -5.469 & -5.544 & 0.967 & -8.527 & -1.091 \\
\hline
\end{tabular}




\section{APPENDIX IV: ROBUSTNESS CHECKS}

\begin{tabular}{|c|c|c|c|c|c|c|c|c|c|}
\hline \multicolumn{10}{|c|}{ Appendix Table 5: Static Panel Regression: Determinants of Risks } \\
\hline & (1) & (2) & (3) & (4) & (5) & (6) & (7) & (8) & (9) \\
\hline VARIABLES & trEDF & $\operatorname{trEDF}$ & $\operatorname{trEDF}$ & VaR & VaR & VaR & covar & covar & covar \\
\hline \multirow[t]{2}{*}{$\operatorname{ROAA}(\%)=\mathrm{L}$} & $-0.214^{* * *}$ & $-0.264 * * *$ & $-0.284^{* * *}$ & $-0.176 *$ & $-0.467 * * *$ & $-0.500 * * *$ & 0.00250 & 0.0276 & -0.0122 \\
\hline & $(0.0552)$ & $(0.0628)$ & $(0.0635)$ & $(0.0968)$ & $(0.0895)$ & $(0.0968)$ & $(0.0414)$ & $(0.0406)$ & $(0.0395)$ \\
\hline \multirow[t]{2}{*}{ Non-Interest Income Share (\%) = L } & $0.00893^{* *}$ & 0.00789 & $0.0137 * * *$ & $0.0171^{*}$ & -0.00701 & $0.0222 * *$ & $0.0390 * * *$ & $0.0135 *$ & $0.0204^{* * *}$ \\
\hline & $(0.00414)$ & $(0.00533)$ & $(0.00442)$ & $(0.00915)$ & $(0.00895)$ & $(0.00920)$ & $(0.00748)$ & $(0.00766)$ & $(0.00766)$ \\
\hline \multirow[t]{2}{*}{ NII Share (\%) X Loan-to-Asset Ratio (\%) = L } & $-0.000198 * * *$ & * $-0.000174 * *$ & $-0.000212^{* * *}$ & $-0.000264 *$ & $4.18 \mathrm{e}-05$ & $-0.000275^{*}$ & $-0.000584 * * *$ & $-0.000224 *$ & $-0.000329 * *$ \\
\hline & $(7.23 e-05)$ & $(8.77 e-05)$ & $(8.14 \mathrm{e}-05)$ & $(0.000160)$ & $(0.000151)$ & $(0.000160)$ & $(0.000129)$ & $(0.000130)$ & $(0.000134)$ \\
\hline \multirow[t]{2}{*}{ Real GDP Growth Rate (\%) } & $-0.0491 * * *$ & $-0.0562^{* * *}$ & $-0.0580^{* * *}$ & $-0.323 * * *$ & $-0.329 * * *$ & $-0.368 * * *$ & $-0.280 * * *$ & $-0.213 * * *$ & $-0.265^{* * *}$ \\
\hline & $(0.0151)$ & $(0.0144)$ & $(0.0142)$ & $(0.0332)$ & $(0.0330)$ & $(0.0313)$ & $(0.0319)$ & $(0.0286)$ & $(0.0282)$ \\
\hline \multirow[t]{2}{*}{ ST Interest Rate (\%) } & -0.000170 & 0.0141 & 0.0169 & $0.0878 * * *$ & $0.160 * * *$ & $0.186 * * *$ & $0.0368 *$ & -0.00173 & $0.0288^{*}$ \\
\hline & $(0.0119)$ & $(0.0122)$ & $(0.0119)$ & $(0.0258)$ & $(0.0191)$ & $(0.0184)$ & $(0.0210)$ & $(0.0188)$ & $(0.0175)$ \\
\hline \multirow[t]{2}{*}{ Gov Structural Balance/Potential GDP (\%) } & $-0.116 * * *$ & $-0.123 * * *$ & $-0.120 * * *$ & $-0.183^{* * *}$ & $-0.227^{* * *}$ & $-0.199 * * *$ & $-0.176 * * *$ & $-0.215 * * *$ & $-0.167 * * *$ \\
\hline & $(0.0126)$ & $(0.0125)$ & $(0.0122)$ & $(0.0191)$ & $(0.0203)$ & $(0.0175)$ & $(0.0181)$ & $(0.0176)$ & $(0.0169)$ \\
\hline \multirow[t]{2}{*}{ Tier 1 Ratio $(\%)=\mathrm{L}$} & -0.00288 & 0.000886 & -0.00500 & $-0.107 * * *$ & $-0.0709 * * *$ & $-0.0851 * * *$ & $-0.0468 * * *$ & $-0.0404 * * *$ & $-0.0428 * * *$ \\
\hline & $(0.0109)$ & $(0.0109)$ & $(0.00862)$ & $(0.0228)$ & $(0.0201)$ & (0.0192) & $(0.0176)$ & $(0.0136)$ & (0.0154) \\
\hline \multirow[t]{2}{*}{ Problem Loans Ratio $(\%)=\mathrm{L}$} & $0.0776 * * *$ & $0.0760 * * *$ & $0.0752 * * *$ & $0.110 * * *$ & $0.0967 * * *$ & $0.115 * * *$ & 0.00355 & $-0.0201 * *$ & 0.00426 \\
\hline & $(0.00857)$ & $(0.00972)$ & $(0.00898)$ & $(0.0217)$ & $(0.0197)$ & $(0.0196)$ & $(0.00825)$ & $(0.00914)$ & $(0.00804)$ \\
\hline \multirow[t]{2}{*}{ Lerner Index $(\%)=\mathrm{L}$} & $-0.0121 * * *$ & & & $-0.0451 * * *$ & & & $0.00905^{*}$ & & \\
\hline & $(0.00362)$ & & & $(0.0116)$ & & & $(0.00548)$ & & \\
\hline \multirow[t]{2}{*}{ Deposit-to-Liability Ratio (\%) = L } & & -0.00341 & & & $-0.0271 * * *$ & & & $-0.0291 * * *$ & \\
\hline & & $(0.00300)$ & & & $(0.00668)$ & & & $(0.00484)$ & \\
\hline \multirow[t]{2}{*}{ Leverage Ratio $=\mathrm{L}$} & & & -0.000696 & & & 0.00380 & & & $0.00858^{* * *}$ \\
\hline & & & $(0.00251)$ & & & $(0.00325)$ & & & $(0.00177)$ \\
\hline Observations & 3,086 & 3,128 & 3,133 & 4,062 & 4,113 & 4,118 & 4,052 & 4,103 & 4,108 \\
\hline
\end{tabular}

Appendix Table 5 presents the static panel regression with bank fixed effects and lagged regressors. 


\begin{tabular}{|c|c|c|c|c|c|c|}
\hline \multicolumn{7}{|c|}{ Appendix Table 6: Robustness Checks for the Determinants of Risks } \\
\hline & (1) & (2) & (3) & (4) & (5) & (6) \\
\hline VARIABLES & covar & covar & VaR & VaR & trEDF & trEDF \\
\hline ROAA (\%) & $\begin{array}{l}-0.188^{* *} \\
(0.0926)\end{array}$ & & $\begin{array}{c}-0.580^{* * *} \\
(0.0913)\end{array}$ & & $\begin{array}{l}-0.142 * * \\
(0.0631)\end{array}$ & \\
\hline Price-to-Book Ratio (\%) & & $\begin{array}{c}0.00120 \\
(0.00118)\end{array}$ & & $\begin{array}{c}-0.00252^{* * *} \\
(0.000841)\end{array}$ & & $\begin{array}{l}-0.000487 \\
(0.000552)\end{array}$ \\
\hline Non-Interest Income Share (\%) & $\begin{array}{l}\mathbf{0 . 0 2 7 3 * * *} \\
(0.00812)\end{array}$ & $\begin{array}{l}0.0214 * * * \\
(0.00646)\end{array}$ & $\begin{array}{c}0.0108^{*} \\
(0.00650)\end{array}$ & $\begin{array}{c}0.00507 \\
(0.00545)\end{array}$ & $\begin{array}{l}0.00539 * * \\
(0.00267)\end{array}$ & $\begin{array}{c}0.00684^{* *} \\
(0.00270)\end{array}$ \\
\hline NII Share (\%) X Loan-to-Asset Ratio (\%) & $\begin{array}{c}-0.000347^{* *} \\
(0.000159)\end{array}$ & $\begin{array}{l}-0.000335^{* *} \\
(0.000142)\end{array}$ & $\begin{array}{c}-0.000263^{* *} \\
(0.000113)\end{array}$ & $\begin{array}{c}-0.000176 * \\
(9.67 \mathrm{e}-05)\end{array}$ & $\begin{array}{c}-9.56 \mathrm{e}-05^{* *} \\
(4.78 \mathrm{e}-05)\end{array}$ & $\begin{array}{c}-0.000105 * * \\
(4.11 \mathrm{e}-05)\end{array}$ \\
\hline Tier 1 Ratio (\%) & $\begin{array}{c}-0.0411^{* *} \\
(0.0189)\end{array}$ & $\begin{array}{c}-0.0557^{* * *} \\
(0.0190)\end{array}$ & $\begin{array}{c}-0.0377^{* * *} \\
(0.0135)\end{array}$ & $\begin{array}{c}-0.0587^{* * *} \\
(0.0140)\end{array}$ & $\begin{array}{c}0.0108 \\
(0.00733)\end{array}$ & $\begin{array}{c}0.00429 \\
(0.00674)\end{array}$ \\
\hline Problem Loans Ratio (\%) & $\begin{array}{c}-0.00559 \\
(0.00811)\end{array}$ & $\begin{array}{l}-0.00516 \\
(0.00795)\end{array}$ & $\begin{array}{c}0.0551^{* * *} \\
(0.0139)\end{array}$ & $\begin{array}{c}\mathbf{0 . 0 5 8 1 * * *} \\
(0.0124)\end{array}$ & $\begin{array}{l}\mathbf{0 . 0 2 9 2 * * *} \\
(0.00461)\end{array}$ & $\begin{array}{l}0.0325 * * * \\
(0.00541)\end{array}$ \\
\hline Real GDP Growth Rate (\%) & $\begin{array}{c}-0.0293 \\
(0.0296)\end{array}$ & $\begin{array}{c}-0.0379 \\
(0.0320)\end{array}$ & $\begin{array}{c}-0.0772 * * * \\
(0.0288)\end{array}$ & $\begin{array}{c}-0.113^{* * *} \\
(0.0283)\end{array}$ & $\begin{array}{l}-0.0221 * * \\
(0.00973)\end{array}$ & $\begin{array}{c}-0.0323 * * * \\
(0.0111)\end{array}$ \\
\hline ST Interest Rate (\%) & $\begin{array}{c}0.0472 \\
(0.0764)\end{array}$ & $\begin{array}{c}0.0123 \\
(0.0655)\end{array}$ & $\begin{array}{c}0.0115 \\
(0.0513)\end{array}$ & $\begin{array}{c}-0.0372 \\
(0.0485)\end{array}$ & $\begin{array}{l}0.165 * * * \\
(0.0224)\end{array}$ & $\begin{array}{l}0.157^{* * *} \\
(0.0214)\end{array}$ \\
\hline Gov Structural Balance/Potential GDP (\%) & $\begin{array}{c}-\mathbf{0 . 0 6 0 2 * * *} \\
(0.0225)\end{array}$ & $\begin{array}{l}-0.0265 \\
(0.0182)\end{array}$ & $\begin{array}{c}-0.0775 * * * \\
(0.0181)\end{array}$ & $\begin{array}{c}-\mathbf{0 . 0 6 1 4} * * * \\
(0.0173)\end{array}$ & $\begin{array}{c}-\mathbf{0 . 0 3 1 7 * * *} \\
(0.00847)\end{array}$ & $\begin{array}{c}-0.0280^{* * * *} \\
(0.00864)\end{array}$ \\
\hline Lerner Index (\%) & $\begin{array}{l}\mathbf{0 . 0 4 1 4} * * * \\
(0.00954)\end{array}$ & $\begin{array}{l}\mathbf{0 . 0 2 5 9 * * *} \\
(0.00681)\end{array}$ & $\begin{array}{c}-0.00271 \\
(0.00864)\end{array}$ & $\begin{array}{l}-0.0168^{* *} \\
(0.00790)\end{array}$ & $\begin{array}{c}0.00345 \\
(0.00345)\end{array}$ & $\begin{array}{c}0.00645 * * \\
(0.00302)\end{array}$ \\
\hline Delta CoVaR (95\%) of Weekly Loss (\%) = L & $\begin{array}{c}\mathbf{0 . 1 8 2} * * * \\
(0.0218)\end{array}$ & $\begin{array}{l}\mathbf{0 . 3 6 8 * * *} \\
(0.0343)\end{array}$ & & & & \\
\hline $\operatorname{VaR}(95 \%)$ of Daily Loss (\%) = L & & & $\begin{array}{l}0.458^{* * *} \\
(0.0399)\end{array}$ & $\begin{array}{l}0.498^{* * *} \\
(0.0389)\end{array}$ & & \\
\hline $\operatorname{logit}(E D F)=L$ & & & & & $\begin{array}{c}0.664^{* * *} \\
(0.0301)\end{array}$ & $\begin{array}{l}0.699 * * * \\
(0.0332)\end{array}$ \\
\hline Observations & 3,864 & 3,830 & 3,867 & 3,833 & 2,971 & 2,943 \\
\hline Year Fixed Effects & Y & Y & Y & Y & Y & $\mathrm{Y}$ \\
\hline Hansen p-Value & 0.280 & 0.322 & 0.691 & 0.699 & 0.105 & 0.503 \\
\hline Robust standard errors in parentheses. ${ }^{* * *}$ & $05, * p<0.1$ & & & & & \\
\hline
\end{tabular}

Appendix Table 6 presents the dynamic panel regression with year fixed effects. 


\begin{tabular}{|c|c|c|c|c|c|}
\hline \multicolumn{6}{|c|}{ Appendix Table 7: Robustness Checks for the Determinants of Profitability } \\
\hline & (1) & (2) & (3) & (4) & (5) \\
\hline VARIABLES & ROAA & ROAE & RAROAA & RAROAE & PriceBook \\
\hline \multirow[t]{2}{*}{ Real GDP Growth Rate (\%) } & $0.100 * * *$ & $1.702 * * *$ & $0.0948 * * *$ & $0.0913 * * *$ & $2.245^{* *}$ \\
\hline & $(0.0235)$ & $(0.395)$ & $(0.0182)$ & $(0.0154)$ & $(0.914)$ \\
\hline \multirow[t]{2}{*}{ ST Interest Rate (\%) } & 0.0124 & -0.503 & $0.125 * * *$ & $0.159 * * *$ & $10.40 * * *$ \\
\hline & $(0.0250)$ & $(0.547)$ & $(0.0290)$ & $(0.0239)$ & $(1.771)$ \\
\hline \multirow[t]{2}{*}{ Gov Structural Balance/Potential GDP (\%) } & $0.0342 * * *$ & $0.653 * *$ & $0.0392 * * *$ & $0.0351 * * *$ & $3.917 * * *$ \\
\hline & $(0.0131)$ & $(0.271)$ & $(0.0131)$ & $(0.0112)$ & $(0.824)$ \\
\hline \multirow[t]{2}{*}{ Claim Growth Rate (\%) } & $4.09 \mathrm{e}-05^{* * *}$ & $0.000205^{*}$ & $1.77 e-05$ & $1.04 \mathrm{e}-05$ & 0.000280 \\
\hline & $(1.08 \mathrm{e}-05)$ & $(0.000118)$ & $(1.29 \mathrm{e}-05)$ & $(1.12 \mathrm{e}-05)$ & $(0.000605)$ \\
\hline \multirow[t]{2}{*}{ Problem Loans Ratio $(\%)=\mathrm{L}$} & $-0.0421 * * *$ & $-0.541 * * *$ & $-0.0379 * * *$ & $-0.0291 * * *$ & $-4.197 * * *$ \\
\hline & (0.00798) & $(0.141)$ & (0.00688) & (0.00647) & $(0.738)$ \\
\hline \multirow[t]{2}{*}{ Cost-to-Income $(\%)=\mathrm{L}$} & $-0.00756 * * *$ & $-0.0806 * * *$ & $-0.00518 * * *$ & $-0.00491 * * *$ & $-0.144 * *$ \\
\hline & (0.00185) & (0.0211) & $(0.00156)$ & $(0.00147)$ & $(0.0563)$ \\
\hline \multirow[t]{2}{*}{ Cost of Funds $(\%)=L$} & $-0.103 *$ & 0.661 & $-0.260 * * *$ & $-0.187 * * *$ & $-13.87 * * *$ \\
\hline & $(0.0548)$ & (1.141) & $(0.0614)$ & $(0.0491)$ & (3.478) \\
\hline \multirow[t]{2}{*}{$\log$ (Assets) $=\mathrm{L}$} & $-0.216 * * *$ & $-3.481 * * *$ & $-0.209 * * *$ & $-0.270 * * *$ & $-12.40 * * *$ \\
\hline & $(0.0560)$ & $(0.820)$ & $(0.0664)$ & $(0.0703)$ & $(4.516)$ \\
\hline Observations & 4,196 & 4,192 & 4,196 & 4,192 & 3,921 \\
\hline R-squared & 0.153 & 0.117 & 0.204 & 0.214 & 0.328 \\
\hline \multicolumn{6}{|c|}{ Robust standard errors in parentheses. $* * * p<0.01, * * p<0.05, * p<0.1$. } \\
\hline \multicolumn{6}{|c|}{ Robustness check is based on static panel regressions with lagged bank-specific independent variables. } \\
\hline
\end{tabular}

Appendix Table 7 presents the static panel regression with bank fixed effects and lagged regressors. 


\begin{tabular}{|c|c|c|c|c|c|}
\hline \multicolumn{6}{|c|}{ Appendix Table 8: Robustness Checks for the Determinants of Profitability } \\
\hline & (1) & (2) & (3) & (4) & (5) \\
\hline VARIABLES & ROAA & ROAE & RAROAA & RAROAE & PriceBook \\
\hline \multirow[t]{2}{*}{ Problem Loans Ratio (\%) } & $-0.0194^{* *}$ & $-0.185^{* *}$ & $-0.0180 * * *$ & $-0.0294 * * *$ & $-1.056^{* * *}$ \\
\hline & $(0.00863)$ & $(0.0927)$ & $(0.00637)$ & $(0.00747)$ & $(0.298)$ \\
\hline \multirow[t]{2}{*}{ Cost-to-Income (\%) } & $-0.0303^{* * *}$ & $-0.367 * * *$ & $-0.00977^{* * *}$ & $-0.0146 * * *$ & $-0.261 * *$ \\
\hline & $(0.00360)$ & $(0.0525)$ & $(0.00269)$ & $(0.00274)$ & $(0.112)$ \\
\hline \multirow[t]{2}{*}{ Cost of Funds (\%) } & $-0.186 * * *$ & $-1.087^{*}$ & $-0.171 * * *$ & $-0.141 * *$ & $-11.78 * *$ \\
\hline & $(0.0622)$ & $(0.641)$ & $(0.0583)$ & $(0.0584)$ & $(4.680)$ \\
\hline \multirow[t]{2}{*}{ Real GDP Growth Rate (\%) } & $0.0702^{* * *}$ & $1.343^{* * *}$ & $0.0560 * * *$ & $0.0458^{* * *}$ & 0.0190 \\
\hline & $(0.0244)$ & $(0.402)$ & $(0.0150)$ & $(0.0171)$ & (1.229) \\
\hline \multirow[t]{2}{*}{ ST Interest Rate (\%) } & $0.0687 *$ & -0.147 & -0.0408 & $-0.105^{* *}$ & -2.422 \\
\hline & $(0.0407)$ & $(0.413)$ & $(0.0450)$ & $(0.0523)$ & (2.034) \\
\hline \multirow[t]{2}{*}{ Gov Structural Balance/Potential GDP (\%) } & -0.00461 & 0.0189 & $0.0555^{* * *}$ & $0.0820 * * *$ & $-1.225^{* * *}$ \\
\hline & $(0.0116)$ & $(0.133)$ & $(0.0174)$ & $(0.0202)$ & $(0.436)$ \\
\hline \multirow[t]{2}{*}{ Claim Growth Rate (\%) } & $5.20 \mathrm{e}-05^{* * *}$ & $0.000313^{* * *}$ & $2.79 \mathrm{e}-05^{* * *}$ & $2.97 e-05 * * *$ & 0.000272 \\
\hline & $(4.12 \mathrm{e}-06)$ & $(2.80 \mathrm{e}-05)$ & $(2.54 \mathrm{e}-06)$ & $(3.96 \mathrm{e}-06)$ & $(0.000264)$ \\
\hline \multirow[t]{2}{*}{ Log(Assets) } & $-0.0671 * *$ & -0.489 & $-0.0868 * * *$ & $-0.0693^{* *}$ & $1.512 *$ \\
\hline & $(0.0297)$ & $(0.316)$ & $(0.0253)$ & $(0.0272)$ & $(0.836)$ \\
\hline \multirow[t]{2}{*}{$\operatorname{ROAA}(\%)=\mathrm{L}$} & 0.0803 & & & & \\
\hline & $(0.0623)$ & & & & \\
\hline \multirow[t]{2}{*}{$\operatorname{ROAE}(\%)=\mathrm{L}$} & & $0.195^{* *}$ & & & \\
\hline & & $(0.0803)$ & & & \\
\hline \multirow[t]{2}{*}{ ROAA/sd(ROAA) (\%) = L } & & & $0.752 * * *$ & & \\
\hline & & & $(0.0231)$ & & \\
\hline \multirow[t]{2}{*}{$\mathrm{ROAA} / \mathrm{sd}(\mathrm{ROAE})(\%)=\mathrm{L}$} & & & & $0.726 * * *$ & \\
\hline & & & & $(0.0254)$ & \\
\hline \multirow[t]{2}{*}{ Price-to-Book Ratio $(\%)=\mathrm{L}$} & & & & & $0.650 * * *$ \\
\hline & & & & & $(0.0249)$ \\
\hline Observations & 4,265 & 4,240 & 4,265 & 4,240 & 3,927 \\
\hline Year Fixed Effects & Y & Y & Y & Y & Y \\
\hline Hansen $\mathrm{p}$-Value & 0.113 & 0.175 & 0.234 & 0.288 & 0.290 \\
\hline \multicolumn{6}{|l|}{ Robust standard errors in parentheses. } \\
\hline$* * * p<0.01, * * p<0.05, * p<0.1$ & & & & & \\
\hline
\end{tabular}

Appendix Table 8 presents the dynamic panel regression with year fixed effects. 


\begin{tabular}{|c|c|c|c|c|}
\hline \multicolumn{5}{|c|}{ Appendix Table 9: Robustness Checks for the Determinants of Profitability } \\
\hline VARIABLES & $\begin{array}{c}(1) \\
\text { pROAA }\end{array}$ & $\begin{array}{c}(2) \\
\text { pROAE }\end{array}$ & $\begin{array}{c}(3) \\
\text { pRAROAA }\end{array}$ & $\begin{array}{c}(4) \\
\text { pRAROAE }\end{array}$ \\
\hline Problem Loans Ratio (\%) & $\begin{array}{c}-0.000598 * * * \\
(0.000137)\end{array}$ & $\begin{array}{l}-0.00165 \\
(0.00811)\end{array}$ & $\begin{array}{c}-0.0108 \\
(0.00664)\end{array}$ & $\begin{array}{c}-0.0199 * * * \\
(0.00730)\end{array}$ \\
\hline Cost-to-Income (\%) & $\begin{array}{c}-\mathbf{0 . 0 0 0 4 1 8} * * * \\
(5.26 \mathrm{e}-05)\end{array}$ & $\begin{array}{l}-0.0130 * * \\
(0.00589)\end{array}$ & $\begin{array}{c}-0.0162 * * * \\
(0.00341)\end{array}$ & $\begin{array}{c}-0.0215 * * * \\
(0.00374)\end{array}$ \\
\hline Cost of Funds (\%) & $\begin{array}{l}-0.00123 * * \\
(0.000493)\end{array}$ & $\begin{array}{l}0.0891 \\
(0.130)\end{array}$ & $\begin{array}{l}-0.113^{* *} \\
(0.0446)\end{array}$ & $\begin{array}{l}-0.0676 \\
(0.0424)\end{array}$ \\
\hline Real GDP Growth Rate (\%) & $\begin{array}{c}\mathbf{0 . 0 0 0 6 7 4} * * * \\
(0.000128)\end{array}$ & $\begin{array}{c}0.0114 \\
(0.0554)\end{array}$ & $\begin{array}{c}0.0808^{* * *} \\
(0.0121)\end{array}$ & $\begin{array}{c}\mathbf{0 . 0 7 5 5 * * *} \\
(0.0136)\end{array}$ \\
\hline ST Interest Rate (\%) & $\begin{array}{l}0.000597^{*} \\
(0.000325)\end{array}$ & $\begin{array}{l}-0.0689 \\
(0.0984)\end{array}$ & $\begin{array}{l}-0.0161 \\
(0.0309)\end{array}$ & $\begin{array}{l}-0.0287 \\
(0.0303)\end{array}$ \\
\hline Gov Structural Balance/Potential GDP (\%) & 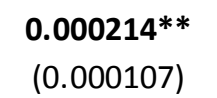 & $\begin{array}{c}0.0230 \\
(0.0222)\end{array}$ & $\begin{array}{l}0.00456 \\
(0.0109)\end{array}$ & $\begin{array}{c}\mathbf{0 . 0 2 6 1 * *} \\
(0.0119)\end{array}$ \\
\hline Claim Growth Rate (\%) & $\begin{array}{l}3.20 \mathrm{e}-07^{*} \\
(1.93 \mathrm{e}-07)\end{array}$ & $\begin{array}{c}5.23 \mathrm{e}-06 \\
(4.77 \mathrm{e}-06)\end{array}$ & $\begin{array}{c}2.31 \mathrm{e}-06 \\
(1.50 \mathrm{e}-05)\end{array}$ & $\begin{array}{c}6.30 \mathrm{e}-06 \\
(1.51 \mathrm{e}-05)\end{array}$ \\
\hline Log(Assets) & $\begin{array}{c}-0.00137 * * * \\
(0.000294)\end{array}$ & $\begin{array}{l}-0.0742 \\
(0.0586)\end{array}$ & $\begin{array}{l}-0.0250 \\
(0.0213)\end{array}$ & $\begin{array}{l}-0.0377 \\
(0.0254)\end{array}$ \\
\hline pre-Tax ROAA = L & $\begin{array}{c}0.0818 \\
(0.0671)\end{array}$ & & & \\
\hline pre-Tax ROAE $=\mathrm{L}$ & & $\begin{array}{l}0.0157 * * \\
(0.00738)\end{array}$ & & \\
\hline PRAROAA $=\mathrm{L}$ & & & $\begin{array}{c}\mathbf{0 . 7 3 1 * * *} \\
(0.0332)\end{array}$ & \\
\hline $\mathrm{pRAROAE}=\mathrm{L}$ & & & & $\begin{array}{c}\mathbf{0 . 6 8 3} * * * \\
(0.0291)\end{array}$ \\
\hline Observations & 4,351 & 4,348 & 4,351 & 4,348 \\
\hline Hansen $p$-Value & 0.0931 & 0.0388 & 0.234 & 0.225 \\
\hline
\end{tabular}

Appendix Table 9 presents the dynamic panel regression with pre-tax profitability measures. 


\section{REFERENCES}

Abedifar, P., P. Molyneux, and A. Tarazi. 2018. "Non-Interest Income and Bank Lending." Journal of Banking and Finance 87 (February): 411- 426.

Acharya, V. V., L. H. Pedersen, T. Philippon, and M. Richardson. 2017. "Measuring Systemic Risk." The Review of Financial Studies 30 (1): 2-47.

Adrian, T., and M. K. Brunnermeier. 2016. "CoVaR." The American Economic Review 106 (7): 1705-1741.

Albertazzi, U., and L. Gambacorta. 2009. "Bank Profitability and the Business Cycle." Journal of Financial Stability 5 (4): 393-409.

Anginer, D., A. Demirgüç -Kunt, and M. Zhu. 2014. "How does Competition Affect Bank Systemic Risk?" Journal of Finanical Intermediation 23 (1): 1-26.

Baele, L., O. De Jonghe, and R. Vander Vennet. 2007. "Does the Stock Market Value Bank Diversification? Journal of Banking and Finance 31 (7): 1999-2023.

Beck, T., O. De Jonghe, and G. Schepens. 2013. "Bank Competition and Stability: CrossCountry Heterogeneity." Journal of Financial Intermediation 22 (2): 218-244.

Beck, T., A. Demirgüç-Kunt, and R. Levine. 2006. "Bank Concentration, Competition, and Crises: First Results.” Journal of Banking and Finance 30 (5): 1581-1603.

Berger, A. N. 1995. "The Profit-Structure Relationship in Banking-Tests of Market-Power and Efficient Structure Hypotheses." Journal of Money, Credit and Banking 27 (2): 404-431.

Berger, A. N., L. F. Klapper, and R. Turk-Ariss. 2009. "Bank Competition and Financial Stability." Journal of Financial Services Research 35 (2): 99-118.

Besanko, D., and A. V. Thakor. 1993. "Relationship Banking, Deposit Insurance and Bank Portfolio Choice. In Capital Markets and Financial Intermediation, edited by C. Mayer and X. Vives. Cambridge, U.K.: Cambridge University Press.

Bikker, A. J., L. Spierdijk, and P. Finnie. 2006. "The Impact of Bank Size on Market Power." DNB Working Papers 120, De Nederland sche Bank, Amsterdam.

Boot, A. W. A., and L. Ratnovski. 2016. "Banking and Trading." Review of Finance 20 (1): 2219-2246.

Borio, C., L. Gambacorta, and B. Hofmann. 2017. "The Influence of Monetary Policy on Bank Profitability." International Finance 20 (1): 48-63.

Boyd, J. H., and G. De Nicoló. 2005. "The Theory of Bank RiskTaking and Competition Revisited." The Journal of Finance 60 (3): 1329-1343. 
Brunnermeier, M. K., G. N. Dong, and D. Palia. 2012. "Banks' Non-Interest Income and Systemic Risk.” SSRN Electronic Journal.

Calmès, C., and Y. Liu. 2009. "Financial Structure Change and Banking Income: A CanadaU.S. Comparison." Journal of International Financial Markets, Institutions and Money 19 (1): $128-139$.

Calmès, C., and R. Theoret. 2010. "The Impact of Off-Balance-Sheet Activities on Banks Returns: An Application of the ARCH-M to Canadian Data." Journal of Banking and Finance 34 (7): 1719-1728.

Claessens, S., N. Coleman, and M. Donnelly. 2016. "Low-for-long Interest Rates and Net Interest Margins of Banks in Advanced Foreign Economies." IFDP Notes, Board of Governors of the Federal Reserve Board, Washington, DC.

De Jonghe, O., M. Diepstraten, and G. Schepens. 2015. "Banks Size, Scope and Systemic Risk: What Role for Conflicts of Interest? Journal of Banking and Finance 61 (Supplement 1): S3-S13.

Dell'Ariccia, G., L. Laeven, and G. A. Suarez. 2017. "Bank Leverage and Monetary Policy's Risk-Taking Channel: Evidence from the United States.” Journal of Finance 72 (2): 613-654.

Demirgüç-Kunt, A., and H. Huizinga. 2010. "Bank Activity and Funding Strategies: The Impact on Risk and Returns." Journal of Financial Economics 98 (3): 626-650.

DeYoung, R., and K. P. Roland. 2001. "Product Mix and Earnings Volatility at Commercial Banks: Evidence from a Degree of Total Leverage Model." Journal of Financial Intermediation 10 (1): 54-84.

DeYoung, R., and G. Torna. 2013. "Nontraditional Banking Activities and Bank Failures During the Financial Crisis." Journal of Financial Intermediation 22 (3): 397-421.

Diebold, F. X., and K. Y1lmaz. 2014. "On the Network Topology of Variance Decompositions: Measuring the Connectedness of Financial Firms." Journal of Econometrics 182 (1): 119-134.

Drechsler, I., A. Savov, and P. Schnabl. 2017. "The Deposits Channel of Monetary Policy." Quarterly Journal of Economics 132 (4): 1819-1876

Elsas, R., A. Hackethal, and M. Holzhauser. 2010. "The Anatomy of Bank Diversification." Journalof Banking and Finance 34 (6): 1274-1287.

Engle, R., F. Moshirian, S. Sahgal, and B. Zhang. 2014. "Non-Interest Income and Global Financial Stability." CIFR Working Paper 015, Centre for International Finance and Regulation, Sydney, Australia. 
Freixas, X., and J.-C. Rochet. 2008. Microeconomics of Banking. Cambridge, MA: MIT Press.

Genay, H., and R. Podjasek. 2014. "What is the Impact of a Low Interest Rate Environment on Bank Profitability?" Chicago Fed Letter 324 (July).

Goddard, J., P. Molyneux, and J. O. Wilson. 2004. "Dynamics of Growth and Profitability in Banking." Journal of Money, Credit and Banking 36 (6): 1069-1090.

IMF (International Monetary Fund). 2017. "Spain: Financial Sector Assessment Report; Technical Note: Determinants of Bank Profitability." IMF Country Report No. 17/339, International Monetary Fund, Washington, DC.

Ho, T., and A. Saunders. 1981. "The Determinants of Bank Interest Margins: Theory and Empirical Evidence." The Journal of Financial and Quantitative Analysis 16 (4): 581-600.

Jiménez, G., J. A. Lopez, and J. Saurina. 2013. "How does Dompetition Affect Bank RiskTaking?" Journal of Financial Stability 9 (2): 185-195.

Keeley, M. C. 1990. "Deposit Insurance, Risk, and Market Power in Banking.” The American Economic Review 80 (5): 1183-1200.

Klein, M. A. 1971. “A Theory of the Banking Firm.” Journal of Money, Credit and Banking 3 (2): 205-218.

Kohler, M. 2014. "Does Non-Interest Income Make Banks More Risky? Retail- Versus Investment-Oriented Banks.” Review of Financial Economics 23 (4): 182-193.

2015. "Which Banks are More Risky? The Impact of Business Models on Bank Stability.” Journal of Financial Stability 16 (February): 195-212.

Kok, C., C. Móré, and C. Pancaro. 2015. "Bank Profitability Challenges in Euro Area Banks: The Role of Cyclical and Structural Factors.” In Financial Stability Review. Volume 1. Frankfurt: European Central Bank.

Laeven, L., and F. Valencia. 2013. "The Real Effects of Financial Sector Interventions During Crises." Journal of Money, Credit and Banking 45 (1): 147-177.

Lepetit, L., E. Nys, P. Rous, and A. Tarazi. 2008. "Bank Income Structure and Risk: An Empirical Analysis of European Banks." Journal of Banking and Finance 32 (8): 1452-1467.

López-Espinosa, G., A. Moreno, A. Rubia, and L. Valderrama. 2012. "Short-Term Wholesale Funding and Systemic Risk: A Global CoVaR Approach." Journal of Banking \& Finance 36 (12): 3150-3162. 
Malik, S., and T. Xu. 2017.” Interconnectedness of Global Systemically-Important Banks and Insurers." IMF Working Papers 17/210, International Monetary Fund, Washington, DC.

Martinez-Miera, D., and R. Repullo. 2010. "Does Competition Reduce the Risk of Bank Failure?" Review of Financial Studies 23 (10): 3638-3664.

Matutes, C., and X. Vives. 1996. "Competition for Deposits, Fragility, and Insurance." Journal of Financial Intermediation 5 (2): 184-216. . 2000. "Imperfect Competition, Risk Taking, and Regulation in Banking." European Economic Review 44 (1): 1-34.

Meiselman, B. S., S. Nagel, and A. K. Purnanandam. 2018. "Judging Banks' Risk by the Profits They Report.” Available at SSRN: https://ssrn.com/abstract=3169730.

Molyneux, P., and J. Thornton. 1992, "Determinants of European Bank Profitability: A Note." Journal of Banking and Finance 16 (6): 1173-1178.

Monti, M. 1972. "Deposit, Credit and Interest Rate Determination Under Alternative Bank Objective Functions." In Mathematical Methods in Investment and Finance, edited by G. P. Szegö and K. Shel. Amsterdam: North-Holland Publishing.

Natalya, M., L. Ratnovski, and R. Vlahu. 2015. "Bank Profitability and Risk-Taking.” IMF Working Paper 15/249, International Monetary Fund, Washington, DC.

Repullo, R. 2004. "Capital Requirements, Market Power, and Risk-Taking in Banking." Journalof Financial Intermediation 13 (2): 156-182.

Sanya, S., and S. Wolfe. 2011. "Can Banks in Emerging Economies Benefit from Revenue Diversification?" Journal of Financial Services Research 40 (1): 79-101.

Shleifer, A., and R. W. Vishny. 2010. "Unstable Banking." Journal of Financial Economics 97 (3): 306-318.

Stiglitz, J. E., and A. Weiss. 1981. "Credit Rationing in Markets with Rationing Credit Information Imperfect." The American Economic Review 71 (3): 393-410.

Stiroh, K. J. 2004. "Diversification in Banking: Is Noninterest Income the Answer?" Journal of Money, Credit and Banking 36 (5): 853-882.

. 2006. "A Portfolio View of Banking with Interest and Noninterest Activities." Journal of Money, Credit, and Banking 38 (5): 1351-1361.

Stiroh, K. J., and A. Rumble. 2006. "The Dark Side of Diversification: The Case of U.S. Financial Holding Companies." Journal of Banking and Finance 30 (8): 2131-2161. 
Vives, X. 2010. Competition and Stability in Banking. Central Bank of Chile Working Papers. 